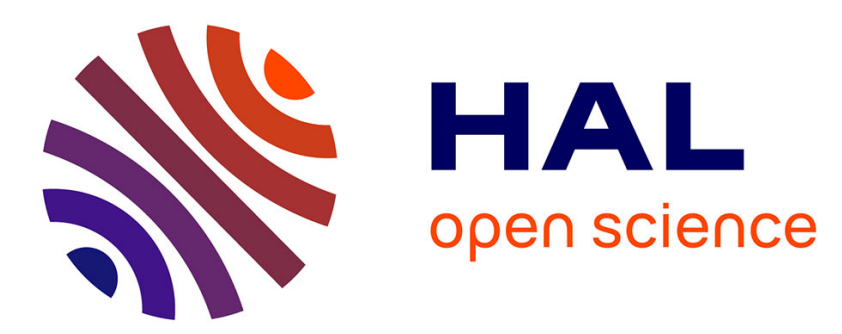

\title{
Seasonal atmospheric transitions in the Caribbean basin and Central America
}

Isabelle Gouirand, Vincent Moron, Bernd Sing

\section{To cite this version:}

Isabelle Gouirand, Vincent Moron, Bernd Sing. Seasonal atmospheric transitions in the Caribbean basin and Central America. Climate Dynamics, 2020, 55 (7-8), pp.1809-1828. 10.1007/s00382-02005356-6 . hal-02962648

\section{HAL Id: hal-02962648 \\ https://hal.science/hal-02962648}

Submitted on 31 Aug 2021

HAL is a multi-disciplinary open access archive for the deposit and dissemination of scientific research documents, whether they are published or not. The documents may come from teaching and research institutions in France or abroad, or from public or private research centers.
L'archive ouverte pluridisciplinaire HAL, est destinée au dépôt et à la diffusion de documents scientifiques de niveau recherche, publiés ou non, émanant des établissements d'enseignement et de recherche français ou étrangers, des laboratoires publics ou privés. 


\title{
Seasonal atmospheric transitions in the Caribbean basin and Central America
}

\author{
Isabelle Gouirand • Vincent Moron • Bernd Sing
}

Received: date / Accepted: date

Abstract The dates of the transition between winter and summer (W2S) and between summer and winter (S2W) regional-scale atmospheric regimes have been defined using daily weather types above and around the Caribbean basin from 1979 to 2017. The uncertainties due to either the use of two different reanalyses (i.e., NCEP-DOE and ERA-Interim) or the parametrization used for the definition of the transition dates have typically a small impact on the interannual variability of the seasonal transitions. When both reanalyses are considered together, the average W2S transition date occurs, on average, on May 13 (with a standard deviation of 9 days) while the S2W transition date occurs, on average, on October 26 (with a standard deviation of 12 days). The atmospheric characteristics associated with both transitions reveal asymmetries in the annual cycle. The W2S transition is rather abrupt and near-synchronous to a rather sharp increase of rainfall, propagating from Central America to the NE of the Caribbean basin,

Corresponding author: Isabelle Gouirand

E-mail: isabelle.gouirand@cavehill.uwi.edu

Isabelle Gouirand

The University of the West Indies

Cave Hill, Barbados

E-mail: isabelle.gouirand@cavehill.uwi.edu

Vincent Moron

Aix-Marseille University, CNRS, IRD, INRAE, Collège de

France, CEREGE

Aix en Provence, France

IRI, Columbia University

Lamont-Doherty Earth Observatory

Palisades, New York, USA

E-mail: moron@cerege.fr

Bernd Sing

The University of the West Indies

Cave Hill, Barbados

E-mail: bernd.sing@cavehill.uwi.edu and a weakening of the Caribbean Low Level Jet. The W2S transition is also not preceded by any significant sea surface temperature (SST) anomalies either in the tropical North Atlantic or the Eastern Pacific. On the other hand, the S2W transition is overall smoother, and anomalously warm (cold) SST over the Caribbean Sea and Gulf of Mexico (Eastern Pacific) during the boreal summer are usually related to a delayed transition (and vice versa). The interannual variations of $\mathrm{S} 2 \mathrm{~W}$ and W2S transitions are mostly independent to each other. The potential and real-time predictability of the W2S transition is explored using a subseasonal-to-seasonal prediction ensemble (11 runs from 1998 to 2017) from the ECMWF model. Its skill is close to zero with a lead time longer than 15-20 days, confirming the weak impact of the antecedent SST upon the W2S transition. The skill suddenly increases from late April, 2-3 weeks only before the mean W2S transition date. It suggests that some atmospheric forcing, operating from synoptic to intra-seasonal time scale, plays a role, but it seems barely related to any occurrence, or sequence, of specific weather types.

Keywords weather type, annual cycle and predictability

\section{Introduction}

As for much of the tropics, the seasonality of the Caribbean basin rainfall broadly follows the seasonal march of the sun with the main rainy season in boreal summer. The rainy season is then synchronous to the seasonal northward shift of the inter-tropical convergence zone ( $\mathrm{Gu}$ and Adler, 2006, Angeles et al., 2010, Gamble and Curtis, 2008) and of the North Atlantic High, the 
weakening of the trade winds, the weakening of the Caribbean Low Level Jet (CLLJ) as well as the warming of the Western Hemispheric warm pool (Wang et al, 2007; Moron, Gouirand, and Taylor, 2015). All these interacting factors favor convective processes, and thus precipitation, over the Caribbean basin and Central America from April-May to October-November (Gamble and Curtis, 2008, Wang, 2007). The Caribbean rainy season is divided into an early (May-July) and a late (September-November) rainy season associated with the two maxima of rainfall (Chen and Taylor, 2002), separated by a relative minimum of rainfall occurring around July (i.e., the mid-summer drought, Magana et al (1999); Curtis and Gamble (2008); Gamble and Curtis (2008); Maldonado et al (2016)).

At inter-annual time scales, the amount of the rainfall is partly modulated by the sea surface temperature (SST) anomalies related to either the El Niño Southern Oscillation (ENSO), the tropical North Atlantic (TNA) SST, and possibly an SST gradient between the East equatorial Pacific (EEP) and the TNA (Giannini et al, 2001, Enfield and Alfaro, 1999, Chen and Taylor, 2002, Taylor et al, 2011; Gouirand et al, 2012, 2016). These past studies have shown that, during the development phase of a warm ENSO event, the late rainy season, in September-November, receives an anomalously low amount of rainfall. This could be related to a reduced number of tropical storms associated either with an increased vertical wind shear or with the warming of the middle and upper troposphere that produces a thermal inversion and inhibits the rainfall (Tang and Neelin, 2004). Conversely, the early rainy season, in April-June, following a warm ENSO event, receives an above normal amount of rainfall (Chen and Taylor, 2002) potentially associated with a warming of the TNA due to the wind-evaporation-sea surface temperature (WES) feedback suggested by Wang, Lee, and Enfield (2007) or to the Gill-type mechanism proposed recently by GarcíaSerrano et al (2017). The regime of the Caribbean rainfall and the factors affecting the amount of rainfall have been summarized by Curtis and Gamble (2008). Ashby et al (2005) analyzed the predictability of the seasonal amount of rainfall for the early and the late rainy season over the Caribbean basin. Their results suggest that the Caribbean sea surface temperature and the sea level pressure over the TNA are influencing the Caribbean rainfall when the decadal signal is kept. The Pacific then has a larger influence at interannual time scales, for both the early and the late season. They have also shown that the factors controlling the early season are not necessary the same as the ones controlling the late season. Most of the researches shown a change in the amount of rainfall but none have shown a change in the length of the rainy season.

However, despite the increased number of research papers on the Caribbean rainfall regime, little focus is placed on the analysis of the transition between seasons, namely from "winter" to "summer" and from "summer" to "winter", and on the characteristics of these transitions. At a first guess, "summer" and "winter" may broadly refer to the wet (i.e., April-May to October-November) and dry regional-scale seasons, respectively, since the Caribbean basin is not associated with alternating low level winds as in "classical" monsoon climates. The triggers of these shifts are still unclear, although the annual cycle of the incoming solar radiation is potentially playing an important role. One way to analyze these transitions consists in estimating a regional-scale average date at which the atmospheric system shifts from the dry to the wet (and vice versa) local-scale season, as it has been already done for the onset of the monsoon in India (Moron and Robertson, 2014), in Indonesia (Moron et al, 2009), in West Africa (Marteau et al, 2009), and in South America (Kousky, 1988), (Marengo et al, 2001), (Gonzalez et al, 2002), (Liebmann et al, 2007), (da Silva and de Carvalho, 2007). Kousky (1988) also suggested that the onset of the rainy season over the Caribbean basin cannot be determined from the Outgoing Longwave Radiation (OLR) due to a lack of a clear seasonal change between the dry and wet seasons. Nevertheless, Mapes et al (2004) performing wavelet analysis on daily OLR dated the onset of the Caribbean rainfall approximately between May 1st and May 10th propagating northeastward from the Southwest of the Caribbean region to Florida (Fig. 6, Mapes et al (2004)). Mapes et al (2004) also highlighted that the beginning of rainfall over the Caribbean presents some similarities with a classical monsoonal climate, despite the lack of alternating nearsurface winds. Moreover, Moron, Gouirand, and Taylor (2015) suggested that there is an abrupt transition between the winter and summer weather types in early May in good agreement with Magana et al (1999). This points to the possibility to determine a regional-scale average date of the transition between winter to summer (hereafter, W2S) and summer to winter (hereafter, S2W) atmospheric conditions over the Caribbean Region and Central America.

Recently, Moron, Gouirand, and Taylor (2015) have identified eight weather types (WT) summarizing the regional-scale daily atmospheric conditions from unfiltered NCEP-DOE $925 \mathrm{hPa}$ winds and interpolated OLR over the Caribbean region. Three out of these eight weather types (i.e., WTs 4, 5 and 6 referred to as "summer" WTs hereafter) show a clear increase of the deep
53 54 
convection across the northern part of South America and Central America and have a larger frequency of occurrence from May to October, while the five other WTs (i.e., WTs 1, 2, 3 and 7, 8 referred to as "winter" WTs hereafter) show increased subsidence around $12^{\circ} \mathrm{N}-28^{\circ} \mathrm{N}$ and are more frequent from November to April, hence showing a strong phase locking with the annual cycle of the Caribbean rainfall. The WTs, based on unfiltered daily data, filter out small-scale features and emphasize recurrent and regional-scale atmospheric patterns, including the more or less gradual transitions related to the annual cycle. This offers the opportunity to estimate a regional-scale date of the W2S and S2W transitions instead of using the noisier rainfall which makes it difficult to identify a signal on this scale. Moreover, the estimate of a transition date will allow to determine the characteristics of the atmospheric and/or oceanic conditions during the W2S transition in boreal spring and the S2W transition in boreal fall over the Caribbean basin and Central America.

The objectives of this paper consist in ; (i) determining the date of the regional-scale shift between the seasons based on the transition of the WTs from winter to summer (and vice versa) atmospheric regimes; (ii) estimating the sensitivity of the dates of the regionalscale shift to the criteria (i.e sequence of summer WT and winter WT during a certain number of days) used to determine the transition date of the WTs and to the use of two different sets of reanalyses (i.e., NCEP-DOE and ERA-Interim) ; (iii) analyzing the atmospheric and oceanic conditions associated with the transition periods ; (iv) evaluating the representativeness of the regional-scale date in subregional-scale rainfall and ; (v) assessing the potential and real-time predictability of the W2S transition.

The paper is structured as follows: the data and methodologies used in the analysis are detailed in Section 2. Section 3 includes the results related to the second, third and fourth objectives, while Section 4 assesses the seasonal and interannual predictability of the W2S transition. Section 5 closes the paper with the discussion.

\section{Data and Methods}

$44 \quad 2.1$ Rainfall and OLR

Daily precipitations have been extracted from the 4 CHIRPS and PERSIAN-CDR data set over the Car4 ibbean basin and Central America $\left(5^{\circ} \mathrm{N}-30^{\circ} \mathrm{N}, 50^{\circ} \mathrm{W}-\right.$ $\left.4100^{\circ} \mathrm{W}\right)$ to determine the change in precipitation prior and after the regional-scale W2S and S2W transitions over this region. The CHIRPS data set developed by the
University of Santa Barbara provides land precipitation with a $0.25^{\circ}$ resolution for the period 1981 to 2017 (Funk et al, 2014) while PERSIAN-CDR provides land and sea precipitation with a $0.25^{\circ}$ spatial resolution for the period 1983 to 2017 (Ashouri et al, 2015). Both data sets were used to gain an estimate of the independence of the results obtained from the data used to perform the analysis. Two indices representing spatialaveraged rainfall, one over the Caribbean basin $\left(10^{\circ} \mathrm{N}-\right.$ $25^{\circ} \mathrm{N}, 90^{\circ} \mathrm{W}-50^{\circ} \mathrm{W}$ ) (hereafter, CarRC for CHIRPS and CarRP for PERSIAN-CDR) and the other one over the Amazon region $\left(1^{\circ} \mathrm{S}-5^{\circ} \mathrm{S}, 75^{\circ} \mathrm{W}-50^{\circ} \mathrm{W}\right)$ (hereafter, AmaR), have been calculated from these data sets to monitor the regional change of rainfall associated with the transitions.

The daily interpolated outgoing longwave radiation is extracted from the $2.5^{\circ}$ data set by (Liebmann and Smith, 1996).

\subsection{Atmospheric data}

All atmospheric data are extracted from the second version of the NCEP reanalyses (i.e., NCEP-DOE, see Kanamitsu et al (2002)) for the period 1979-2017, within the region $8.75^{\circ} \mathrm{N}-31.25^{\circ} \mathrm{N}, 98.75^{\circ} \mathrm{W}-56.25^{\circ} \mathrm{W}$ at an horizontal resolution of $2.5^{\circ}$. Zonal and meridional wind data at $925 \mathrm{hPa}$ are also extracted from ERAInterim to update the time series of WTs from Moron, Gouirand, and Taylor (2015) (see section 2.5). The Caribbean Low Level Jet index (CLLJ, compare Amador (2018)) was calculated by averaging the $925 \mathrm{hPa}$ zonal wind over the area $10^{\circ} \mathrm{N}-17.5^{\circ} \mathrm{N}, 80^{\circ} \mathrm{W}-65^{\circ} \mathrm{W}$, and the Choco Jet (CJ, see Poveda and Mesa (2000)) was calculated by averaging the $925 \mathrm{hPa}$ zonal wind over the area $5^{\circ} \mathrm{S}-7^{\circ} \mathrm{N}, 85^{\circ} \mathrm{W}-75^{\circ} \mathrm{W}$, to determine their influence in the spring and fall transitions.

The precipitable water is used to estimate the amount of water available in the atmospheric column prior and after the W2S and S2W transitions in spring and fall. A spatially averaged index has then been created to represent the regional average of precipitable water (hereafter, CarPW) in the atmosphere over the Caribbean basin between $10^{\circ} \mathrm{N}-25^{\circ} \mathrm{N}, 90^{\circ} \mathrm{W}-50^{\circ} \mathrm{W}$. The dew point for the Caribbean basin was computed from pressure, temperature and specific humidity at 2 meters from Clausius - Clapeyron law. Then, the following equation $\mathrm{Td}=\mathrm{T}-((100-\mathrm{RH}) / 5)$ is used to compute the dew point. 
An ensemble of 11 runs covering the period 1998-2017 have been extracted from the S2S database at the International Research Institute for Climate and Society (https://iridl.ldeo.columbia.edu/SOURCES/ .ECMWF/.S2S/). The ECMWF forecasting system is referred to as Var-EPS-monthly, which is a merged 47 days (from day 0 to a lead time of 46 days) ensemble system updated twice (each Mondays and Thursdays) a week. We use two slightly different model configurations (CY43R23 for the starting dates before June 6 and CY45R1 thereafter) due to the fact that 20 years of retrospective forecasts are performed each time that a new version of the model is available (Moron and Robertson, 2020). The EPS integration uses an atmospheric model at Tco639 resolution (about $16 \mathrm{~km}$ ) up to day 15 and Tco319 (about 32km) after day 15 .

The WTs for the ECMWF runs are computed on the ensemble of the 11 runs starting from March 29 to May 10, i.e., 13 different starting dates leading to a full set of 13 times 47 days times 11 runs times 20 years (thus, in total 134420 ) days. The $925 \mathrm{hPa}$ zonal and meridional wind components have been extracted and linearly interpolated onto the $2.5^{\circ}$ grid of ERA and NCEP. The Euclidean distances have been computed between the standardized anomalies (over the whole available time period, so keeping the annual cycle as in the reanalyses) of the zonal and meridional ECMWF $925 \mathrm{hPa}$ winds (OLR is not used at this step since it is not available in this S2S ensemble) and the centroids of the $8 \mathrm{WTs}$ for $925 \mathrm{hPa}$ winds obtained from days consistent between both reanalyses. The smallest Euclidean distance attributes then each day of the 11 runs of the S2S ensemble to one of the 8 WTs.

\subsection{Sea surface temperatures}

The daily sea surface temperatures have been extracted from the NOAA OISST v2 high resolution data set. The OISST is available from 1981 to 2017 with a spatial resolution of $0.25^{\circ}$ and has been selected for the region extending from $15^{\circ} \mathrm{S}$ to $45^{\circ} \mathrm{N}$ and from $100^{\circ} \mathrm{W}$ to $10^{\circ} \mathrm{E}$ (May et al, 1998; Reynolds et al, 2002). It is used to determined the average state of the sea surface temperature prior and following the date of the W2S and S2W regional-scale transitions. Five SST indices are computed: (i) the TNA index corresponding to the average of SST over the region $9^{\circ} \mathrm{N}-18^{\circ} \mathrm{N}$ and $80^{\circ} \mathrm{W}-60^{\circ} \mathrm{W}$, (ii) the tropical East Pacific index (PAC) corresponding to the average of SST over the region $7^{\circ} \mathrm{N}-16^{\circ} \mathrm{N}$ ) and $110^{\circ} \mathrm{W}-85^{\circ} \mathrm{W}$, (iii) the EEP index corresponding to the average of SST over the region $5^{\circ} \mathrm{S}-$ $5^{\circ} \mathrm{N}$ and $110^{\circ} \mathrm{W}-85^{\circ} \mathrm{W}$, (iv) the Gulf of Mexico index (GMEX) corresponding to the average of SST over the region $18^{\circ} \mathrm{N}-25^{\circ} \mathrm{N}$ and $95^{\circ} \mathrm{W}-80^{\circ} \mathrm{W}$, and (v) the Caribbean Sea index (CARS) corresponding to the average of SST over the region $9^{\circ} \mathrm{N}-18^{\circ} \mathrm{N}$ and $85^{\circ} \mathrm{W}-65^{\circ} \mathrm{W}$.

2.5 The definition of W2S and S2W transition dates from the weather types

The WTs determined by Moron, Gouirand, and Taylor (2015) are based on the $k$-means dynamical clustering of the standardized unfiltered (i.e., the annual cycle is kept) anomalies of the $925 \mathrm{hPa}$ wind fields that provides a good description of low-level circulation and interpolated daily OLR. In this study the WTs from Moron, Gouirand, and Taylor (2015) have been updated till 2017 and re-computed using two different data sets: the NCEP-DOE and the ERA-Interim reanalyses (concatenated with the same interpolated OLR dataset) to evaluate the sensitivity of the cluster analysis to the reanalyses used to determine the WTs. A total of $92 \%$ of the days are clustered in the same WTs. Most of the discrepancies between both reanalyses appear around the 110th and 130th day of the year and around the 300th day, hence just before the early rainy season and at the end of the late rainy season (not show), respectively. The sensitivity of the estimation of the transition dates due to both reanalyses is evaluated below.

The W2S transition and S2W transition dates have been estimated from the daily sequence of WTs (Moron, Gouirand, and Taylor, 2015). The protocol is fairly similar to the one used to define an "agronomical" onset of rainfall (Bombardi et al, 2019). In this definition, the first (or last for the withdrawal) sequence of consecutive wet days receiving a significant amount of rainfall without a too long dry spell thenafter (or before for the withdrawal). We adapted this algorithm by replacing the daily rainfall by the daily 8 WTs coded into a binary vector either as "summer" (i.e., the WTs $4,5,6$ ) or "winter" (i.e., the WTs 1, 2, 3, 7, 8) ones. The W2S transition date is defined as the initial sequence of consecutive "summer" WTs without a too long sequence of "winter" WTs thenafter while the S2W transition date is defined symmetrically as the last sequence of consecutive "summer" WTs without a too long sequence of "winter" WTs before.

Two sensitivities are evaluated in this study: (i) the sensitivity to the parametrization (i.e., to the length of the spell of winter and summer WTs), and (ii) the sensitivity of the date of transition to the reanalyses (NCEP-DOE vs. ERA-Interim). First, the length of the spell of consecutive days of seasonal WTs, followed (or not) by a spell of opposed WTs is always subjective. 
Therefore a first probabilistic choice has been based on the combinations having a similar (40-60\%) conditional probability to randomly occur (assuming independence and equal probability of summer and winter WTs to occur), thus excluding combinations with a too low probability. The parameters include the following combinations for W2S: a sequence of S (ranging from 3 to 10) consecutive days of summer WTs not followed by $\mathrm{W}$ consecutive days with winter WTs during a spell of $\mathrm{P}$ days following the last summer WTs of the initial sequence. Here, W equals 2 when $\mathrm{P}$ is between 4 and 5, 3 when $\mathrm{P}$ is between 8 and 12 and lastly 4 when $\mathrm{P}$ is between 17 and 27. This gave a total of 144 different combinations (i.e., 16 when $\mathrm{W}=2 ; 40$ when $\mathrm{W}=3$ and 88 when $\mathrm{W}=4)$. The criteria for the $\mathrm{S} 2 \mathrm{~W}$ transition are symmetrically reversed.

Secondly, the sensitivity of the transition date to the reanalyses has been estimated for four different "scenarios" based on the reanalysis used to determine the WTs: (1) In the "NCEP" scenario, the dates of transition are determined from the WT time series from NCEP-DOE only ; (2) In the "ERA" scenario, the dates of transition are determined from the WT time series from ERAInterim only ; (3) In the "NCEP+ERA" scenario, a new daily WT time series corresponds to the WTs common to both NCEP-DOE and ERA-Interim based on the 8 WTs. The days having different WTs (amongst the 8 WTs) between both reanalyses are coded as missing value. The transition dates are then calculated based from this new daily WT time series ; (4) In the "NCEP+ERA1" scenario, the eight WTs are first coded into summer and winter categories. Then a new daily WTs timeseries is created based on the common daily WTs in both reanalyses, while the inconsistent days are coded as missing value. The average of the 144 requests from the NCEP+ERA1 scenario have been calculated and this average is then used as reference from section 3.2 .

The criteria used to analyze the predictability of W2S transition dates (in Section 4) from the eleven ECMWF runs are reduced to seven requests out of the 144 described above. The seven requests used to determine the date of the shift between winter to summer WTs correspond the following criteria (with "S" representing the number of consecutive summer WTs, "W" the number of consecutive winter WTs and "P" the number of day following the last summer WTs in which we are looking for the "W" number of winter WTs): (i) $\mathrm{S} 1=5 ; \mathrm{W} 1=3 ; \mathrm{P} 1=13 ;$ (ii) $\mathrm{S} 2=6 ; \mathrm{W} 2=3 ; \mathrm{P} 2=16$; (iii) $\mathrm{S} 3=7 ; \mathrm{W} 3=3 ; \mathrm{P} 3=16 ;$ (iv) $\mathrm{S} 4=6 ; \mathrm{W} 4=4 ; \mathrm{P} 4=27$; (v) $\mathrm{S} 5=5 ; \mathrm{W} 5=4 ; \mathrm{P} 5=24 ;$ (vi) $\mathrm{S} 6=3 ; \mathrm{W} 6=4 ; \mathrm{P} 6=20$; (vii) $\mathrm{S} 7=5 ; \mathrm{W} 7=2 ; \mathrm{P} 7=9$. The correlations between the 7 requests and the 137 other requests is, on average, equal to $0.64,0.72,0.62,0.78,0.73,0.77$ and 0.62 respectively.

\section{Results}

3.1 Sensitivity of the date of transition

The results indicate that a regional-scale W2S transition occurs around May 14, 13, 18 and 13, on average over the 39 years and the 144 requests for the NCEP, ERA, NCEP+ERA and NCEP+ERA1 scenarios. NCEP+ERA leads, as expected, to the latest average date since it is the most conservative choice by excluding the days classified differently in NCEP-DOE and ERA-Interim (amongst the $8 \mathrm{WTs}$ ). The intrascenario variability (i.e., between the 144 requests of each scenario defined in section 3.5) is rather weak as suggested by the error bars of the NCEP+ERA1 scenario (Fig. 19). The average correlations between the 144 requests equal $0.74,0.77,0.68$ and 0.72 (significant according to a Monte Carlo test at $99 \%$ level) for NCEP, ERA, NCEP+ERA and NCEP+ERA1 scenario respectively. The average intra-scenario standard deviation (sd) amongst the 144 requests varies between 4.0 (NCEP), 3.2 (ERA), 5.7 (NCEP+ERA) and 4.0 $(\mathrm{NCEP}+\mathrm{ERA} 1)$ days, while the average interannual sd equals to 10.4 (NCEP), 9.2 (ERA), 11.4 (NCEP+ERA) and 9.3 (NCEP+ERA1) days. The percentage of common variance amongst the 144 requests for each scenario is also high with $74 \%$ (NCEP), $78 \%$ (ERA), $68 \%$ (NCEP+ERA) and $72 \%(\mathrm{NCEP}+\mathrm{ERA} 1)$, respectively. Therefore, in each of the four scenarios, the interannual variability is larger than the intra-scenario spread between the 144 requests. These results thus indicate a weak sensitivity of the W2S transition date to the criteria selected for each request (i.e., criteria S, W and $\mathrm{P}$ presented in section 2.5).

The results for the $\mathrm{S} 2 \mathrm{~W}$ transition indicate an average date occurring around October 26 (NCEP), 26 (ERA), 22 (NCEP+ERA) and 26 (NCEP+ERA1). The average intra-scenario sd varies between 5 to 6 days, while the interannual average sd of each scenario equals 11.4 (NCEP), 12.0 (ERA), 13.1 (NCEP+ERA) and 11.6 (NCEP+ERA1) days. The variability amongst the 144 requests of NCEP+ERA1 scenario is small (see Fig. 1b), and the percentage of common variance between the 144 requests of each scenario equals to $66 \%$ (NCEP), 64\% (ERA), 66\% (NCEP+ERA) and 65\% (NCEP+ERA1). This indicates that there is a small sensitivity of the S2W transition date to its parametrization. The S2W dates of regional-scale transition are neither sensitive to the requests nor to the reanalysis, as it is observed for the W2S transition.
57 
Thus, on average, the regional-scale atmospheric shift from the wet to the dry season, the W2S transition, occurs on May 13 and the S2W transition occurs on October 26 implying that the duration of the wet season is 165-166 days. The correlations between the interannual W2S and S2W transition dates are weak and not significant (-0.14 between W2S and S2W and 0.13 between S2W and W2S seven months after, respectively) for the period 1979-2017. This suggests that these transitions are statistically independent from each other. This result also suggests that the spring and fall shifts may be influenced by different factors such as the SST over the Tropical North Atlantic or over the Pacific as it has been observed for the rainfall amount received during the early and late seasons (Taylor et al, 2002, Ashby et al, 2005).

\subsection{Regional-scale transition date vs. sub-regional rainfall}

A cluster analysis has been performed on the standardized mean annual cycle of rainfall (i.e., climatological daily mean amounts are standardized to zero mean and unit standard deviation) using the CHIRPS data set (Funk et al, 2014). It aims to cluster the annual cycle of rainfall over the Caribbean region independently on the total annual amount of rainfall. Eight annual regimes have been retained. The annual cycle of each area has then been compared with the regional-scale W2S and S2W dates of transition previously defined (Fig. 2).

The eight regions highlighted by the classification are referred as follow: in the north, regions 1 and 2 correspond to South and North Florida, respectively (orange and yellow in Fig. 2). Region 3 includes the western and central part of Cuba, the northern Bahamas islands, Belize and the Pacific side of Central America (blue in Fig. 2), while region 4 aggregates the eastern part of Cuba, the southern Bahamas islands, Jamaica, Hispaniola and Puerto Rico (brown in Fig. 2). The lesser Antilles, Aruba, Bonaire and Curacao islands and the north of Honduras belong to region 5 (light blue) while region 6 (green in Fig. 2) associates the Caribbean side of Costa Rica, Honduras, the eastern part of Venezuela and the southern Windward Islands. In the south, Colombia, Panama and the Pacific side of Costa Rica constitute region 8 (red) and central part of Venezuela is defined as region 7 (dark blue in Fig. 2). Note that regions 3, 4 and 5 are similar to the clusters 1, 2 and 4 identified by Jury et al (2007) who only focused their study on the northern Caribbean Islands.

Four regions (2, 3, 4 and 8) present the classical annual cycle of the Caribbean region, i.e., a dry season from November to April and a wet season from May to October with two maxima of rainfall separated by a reduced amount of rainfall usually associated to the mid-summer drought (Curtis and Gamble, 2008). These regions differ slightly from each other by the timing of the increase of rainfall and the date of the two rainfall maxima. Indeed, the rainfall starts first in regions 8 and 7 , then in regions 4 and 3 following an almost northward progression. The sharp increase of rainfall in region 8 occurred before the average regional-scale W2S transition date. Regions 1, 2, 6 and 7 do not show a clear bi-modality of rainfall during the wet season. Region 7 presents a bell shape distribution of rainfall suggesting that the dry and wet season follow the annual solar cycle, while region 5 shows a progressive increase of rainfall from April to November with a maximum occurring in late September-October, possibly related to the tropical storm activity. Region 6 has two maxima of rainfall, one in July and the other in November, but the maxima of region 6 are delayed compared to the usual bi-modality of the rainy season associated with the Caribbean region. The delayed maximum in June seems to coincide with the maximum intensity of the CLLJ (Muñoz et al, 2008). Fig. 2 also points out that the mid-summer drought is not marked over the northern part of South America and the Eastern Antilles, the Caribbean side of Central America and Florida but is clear over the Pacific side of Central America and the north-western part of the Greater Antilles. The results obtained with this classification are relatively similar to the one from Martinez et a (2019) that did not include data over the northern part of South America. The main difference resides in the bundling of the southern part of Florida with the NW Caribbean while this classification separates them. This classification also highlights the difference in the mean annual cycle between the Pacific and Caribbean side of Central America suggesting that several factors are influencing the rainfall in these regions such as the contrast ocean-land.

The average W2S date of transition obtain from the WTs thus corresponds to an an almost synchronous and abrupt increase of rainfall over the whole Caribbean and Central America region, especially for the regions forming a SW-NE band stretched from region 3 to region 4 (Fig. 2). The W2S transition date occurs after the increase in rainfall over Columbia and Panama and before the increase of rainfall in Florida where the increase starts approximately 20 days after the rest of the Caribbean, in agreement with Mapes et al (2004). This abrupt regional-scale increase detected even in a climatological time series averaging more than three decades suggests a strong solar forcing and is fully consistent with the rather reduced sd of the W2S transition at interannual time scale. Note that the Leeward Islands (re- 

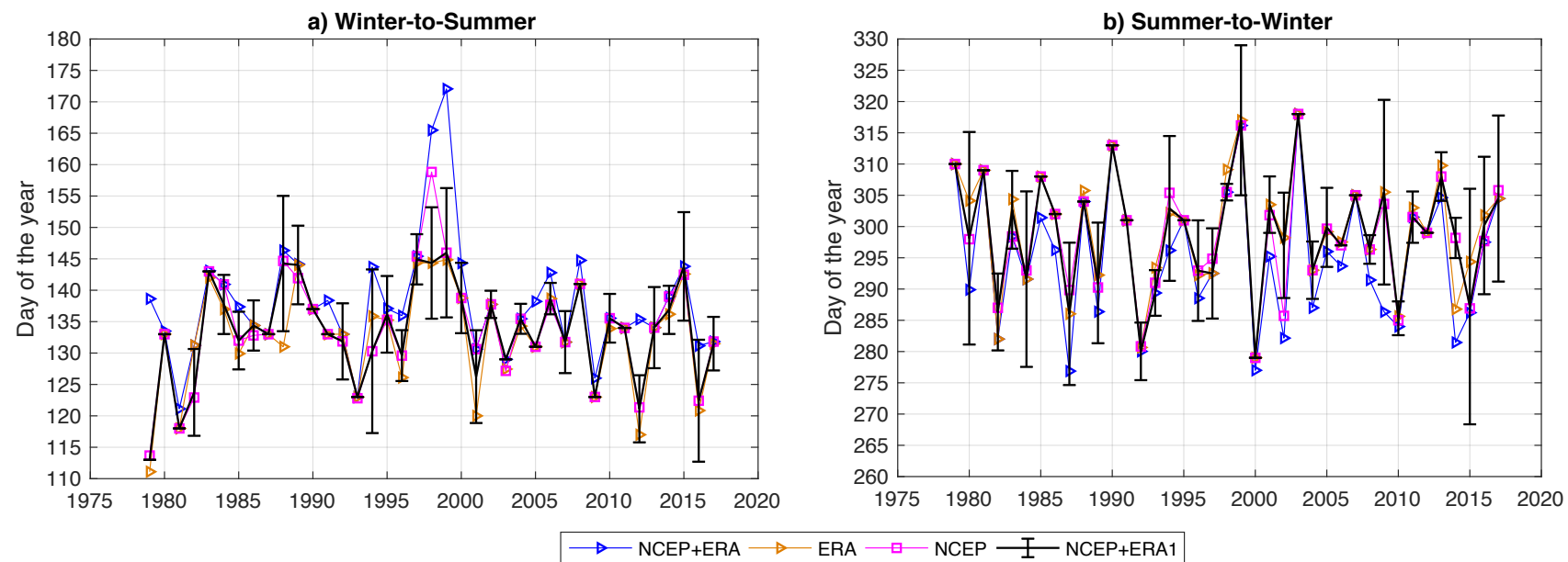

Fig. 1 (a) Day of the W2S transition on the average of the 144 requests for the NCEP+ERA1 scenario (black line with error bars corresponding to $\pm 1 \mathrm{sd}$ ), for NCEP+ERA scenario (blue line with triangle), ERA scenario (orange line with triangle) and NCEP scenario (pink line with square); (b) same as (a) but for the S2W transition.

gion 5 on Fig. 22 show a gradual increase from the first week of April and thus differ slightly from the rest of the Caribbean. The other interesting note concerns region 6 (the Caribbean side of Central America) that presents a maximum of rainfall when a reduced amount of rainfall is observed over the other regions, especially in region 3 where the mid-summer drought has the strongest signal. This could be mostly related to the effect of the CLLJ on the rainfall pattern, an increased CLLJ promoting divergence over most of the Caribbean basin and thus reduced rainfall except on the windward side of the Central America isthmus where the rainfall then increases in mean. To summarize, the W2S transition seems to be first initiated over South America, Panama and Costa Rica, maybe due to the northward shift of the Pacific ITCZ, and then extends a few days later over the northern part of Central America and through the Caribbean basin. The results thus suggest that the average regional-scale $\mathrm{W} 2 \mathrm{~S}$ transition date represents a good estimate of the time at which the regime shifts from dry-to-wet season over most of the Caribbean and Central America region.
3.3 Daily OLR, WTs and Caribbean rainfall vs. average date of transition

The climatology of the daily OLR, the daily WTs and the daily average of Caribbean rainfall have been plotted against the climatological W2S and S2W transition dates (Fig. 3). The OLR time-latitude diagram (Fig. 3), indicates a pulse of convection at $15^{\circ} \mathrm{N}-20^{\circ} \mathrm{N}$ shortly after the average date of the W2S transition, while the S2W transition seems to be smoother. Fig. 3 also highlights the northward migration of the convection over the northern part of South America. Nevertheless, the main deep convection center (i.e., the intertropical convergence zone) at these longitudes $\left(80^{\circ} \mathrm{W}-60^{\circ} \mathrm{W}\right)$ never crosses $10^{\circ} \mathrm{N}$. This emphasizes the importance of the land-sea contrast in keeping the convection locked inland over South America and suggests different mechanisms in action between South America and the Caribbean Sea. The cooler Caribbean sea surface temperature associated with coastal upwelling along the northern coast of South America combined with the mean anticyclonic circulation could indeed inhibit the further northward shift of the ITCZ while the vegetation over South America may contribute to the low level moisture and fuel, at least partly, the deep convection. The climatology of the SST superimposed with the climatological OLR (Fig. 3a) indicates a gradual increase of SST from $26^{\circ} \mathrm{C}$ to $27^{\circ} \mathrm{C}$ over the Caribbean Sea around the W2S (S2W) transition date. This suggests that the SST are not likely to trigger alone neither the W2S nor the S2W transition, although SST warmer than $26^{\circ} \mathrm{C}$ (Zhang, 1993) could still be a sine qua non condition for deep convection to occur at the W2S transition time. 

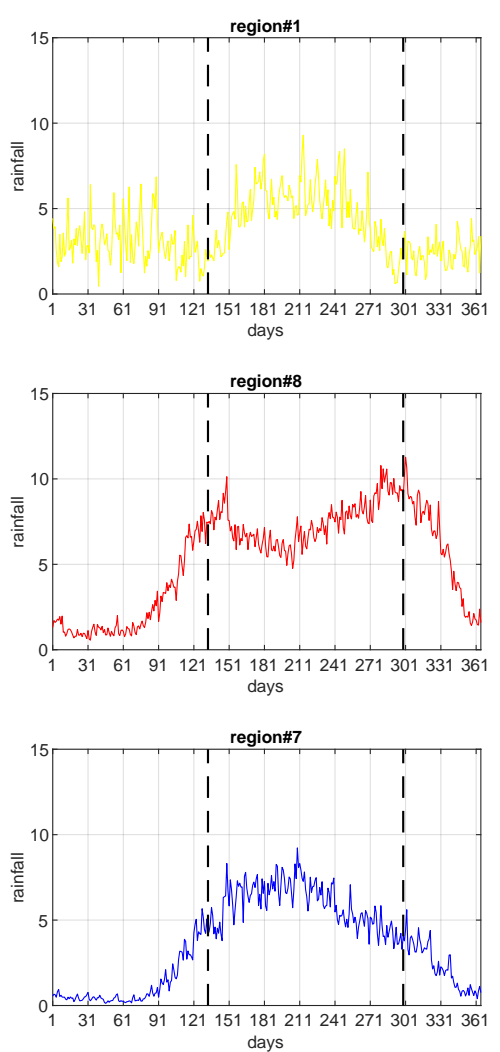
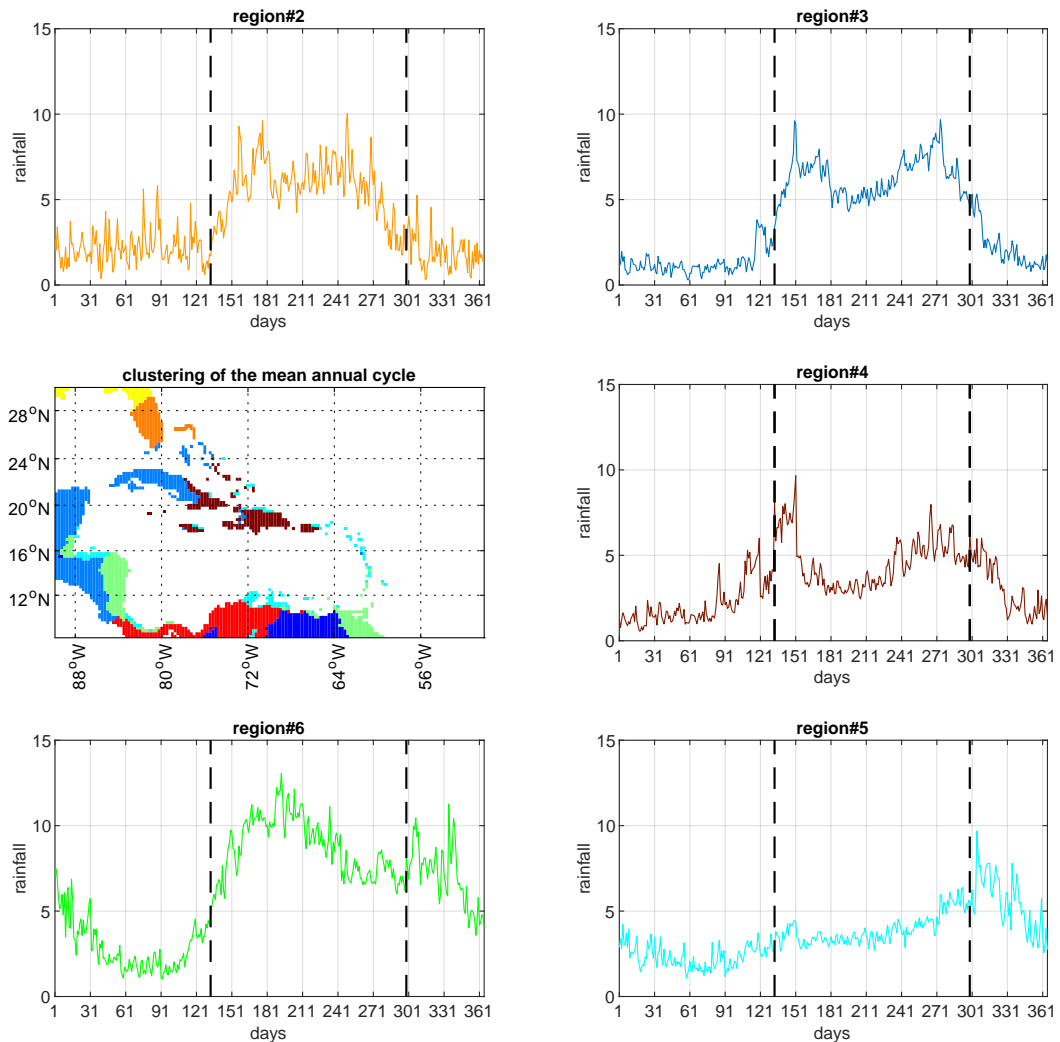

Fig. 2 Clustering of the mean annual cycle of daily rainfall. The daily rainfall are extracted from CHIRPS data set and the climatological daily mean on the whole period 1981-2017 is then standardized to zero mean and unit variance. The clustering is done on the leading 25 principal components explaining $75 \%$ of the total variance. The vertical dashed line refers to the mean S2W and W2S transition dates from the NCEP+ERA1 scenario (May 13 and October 26)

Fig. 3b,c presents the daily distribution of the WTs and the spatially averaged daily rainfall over the Caribbean basin and Central America (i.e., region between $\left.5^{\circ} \mathrm{N}-30^{\circ} \mathrm{N}, 50^{\circ} \mathrm{W}-100^{\circ} \mathrm{W}\right)$ from January 1 st 1981 to December 31st 2017 from CHIRPS. The annual sequences of WTs and spatially averaged daily rainfall are obviously largely similar. The wintertime WTs (red and orange colors on Fig. 3b) are clearly associated to drier conditions while those occurring in summer (blue and green colors on Fig. 3p) are associated to wetter conditions. Both WTs and rainfall distribution show a rapid W2S transition around the regional-scale transition date, while the $\mathrm{S} 2 \mathrm{~W}$ transition is smoother in agreement with the smaller representativeness of the $\mathrm{S} 2 \mathrm{~W}$ date in subregional rainfall. Therefore Fig. 3 b,c illustrates again clearly the strong seasonality in the WTs and in the rainfall regime over the Caribbean basin and Central America and supports the asymmetrical behaviour of the spring and fall transition, W2S being abrupt and strongly locked to subregional rainfall regimes while $\mathrm{S} 2 \mathrm{~W}$ is more gradual and less locked to the subregional rainfall regimes. In consequence, the
S2W transition date has a lower accuracy as a regionwide indicator of the shift of rainfall from wet to dry.

\subsection{Rainfall anomalies vs. yearly transition dates}

In order to further investigate the fingerprints of the regional-scale W2S and S2W transitions on rainfall, weekly amounts of rainfall have been calculated starting 4 weeks before the yearly W2S and S2W transition dates and up to two weeks thereafter. Note that the weeks prior to the transition dates are identified with $(-1)$ ending the day before the transition day, while the weeks after are identified with $(+1)$ starting with the transition day. First, the weekly average amount of rainfall for the fourth week (week4(-1)) before the W2S and S2W transition dates has been calculated (Fig. 4 a,g). Then, the difference between week3(-1) and week4(-1) is computed and so on till week2(+1) (Fig. $4 \mathrm{~b}-\mathrm{f}, \mathrm{h}-\mathrm{l}$ ).

On average, the Caribbean region is receiving less than $5 \mathrm{~mm} /$ day of rainfall a month before the W2S transition date, with the exception of Panama and the Costa Rica (4-6mm/day) located in the exit area of the 
(a)

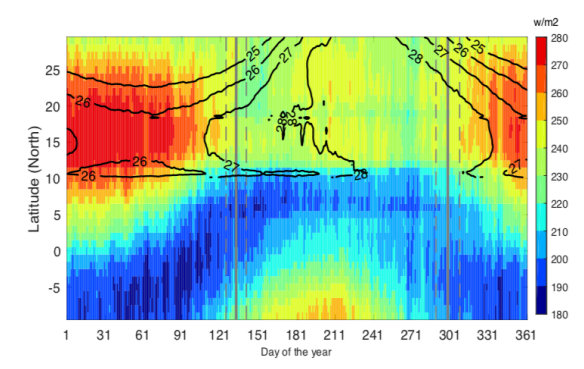

(b)

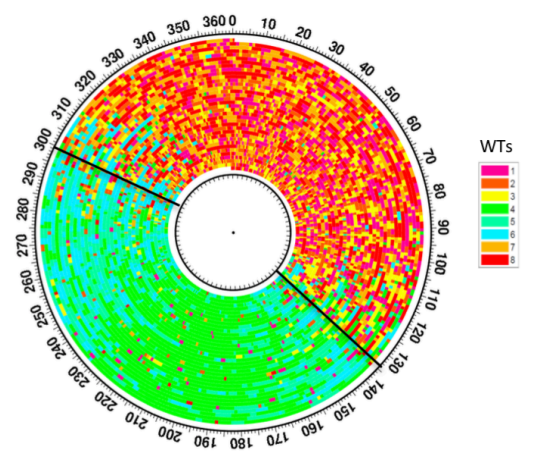

(c)

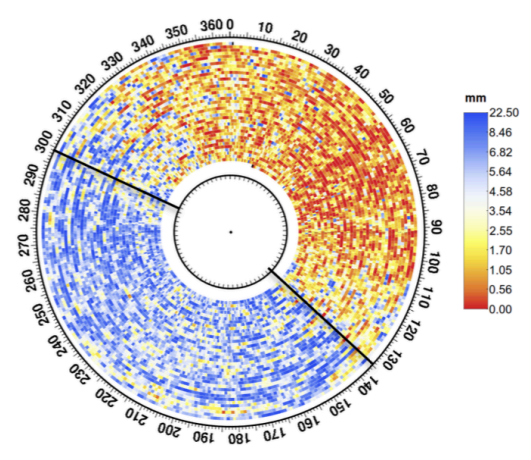

Fig. 3 (a) Daily evolution of the OLR (shadings in $\mathrm{W} / \mathrm{m}^{2}$ ) and SST (contours in degres C) daily mean climatology for each latitude from $10^{\circ} \mathrm{N}$ to $30^{\circ} \mathrm{N}$ averaged between $80^{\circ} \mathrm{W}-50^{\circ} \mathrm{W}$. (b) WTs from the 1st January 1981 (innermost circle) to the 31st of December 2017 (outermost circle). On the circle 0 represents all the January 1st and each complete circle represent one year; (c) same as (b) but for the daily rainfall spatially averaged over the Caribbean basin and Central America $\left(5^{\circ} \mathrm{N}-30^{\circ} \mathrm{N}\right.$, $50^{\circ} \mathrm{W}-100^{\circ} \mathrm{W}$, in $\mathrm{mm}$ ). The radial lines on the circles indicated the $\mathrm{W} 2 \mathrm{~S}$ and $\mathrm{S} 2 \mathrm{~W}$ average transition dates.

CLLJ and part of Colombia affected by the CJ (compare Fig. 4 ). At week3(-1), the rainfall increases by $1 \mathrm{~mm} /$ day with a SW-NE pattern from south of Central America towards Hispaniola (Fig. 4 p). From week3(1) to week $2(-1)$, the weak change in rainfall is mainly located over the east of South America and Central America (Fig. 4F). One week before the W2S transition (Fig. 4 $\mathrm{d}$ ), rainfall increases by $2 \mathrm{~mm} /$ day mainly over Costa Rica and Panama while the amount of rainfall over the Caribbean islands remains the same as before. Then, between week1(+1) and week1(-1), corresponding to the difference in rainfall after vs. prior to the W2S transition date, the daily rainfall shows a more than $3 \mathrm{~mm}$ increase over the whole Caribbean basin and Central America, with a maximum increase over the Pacific side of Nicaragua and Salvador and stretching toward the Greater Antilles (Fig. 4 4 ). During week2(+1), the rainfall still increases over the northern part of Central America but remains rather constant over the Caribbean Islands (Fig. 4F). The increase in rainfall occurs earlier over the southern part of Central America (Costa Rica, Panama and Nicaragua) compared to the rest of the Caribbean basin in agreement with Fig. 2. These results support the abrupt shift in rainfall and the rather simultaneous change in the regime of rainfall over the whole Caribbean basin and Central America as well as the accuracy of the WT-transition W2S date (Moron, Gouirand, and Taylor, 2015) to, in fact, represent the dry-to-wet transition in the Caribbean regime of rainfall.

Four weeks before the S2W transition, the Caribbean basin and Central America are receiving more than $6 \mathrm{~mm} /$ day of rainfall over the Greater Antilles and $12 \mathrm{~mm} /$ day over Central America (Fig. $4 \mathrm{~g}$ ). The rela- tively dry conditions observed over the southern Caribbean Sea may be firstly related to the regional-scale anticyclonic conditions under the Azores/Bermuda high, and cool SST due to the upwelling offshore of South America may reinforce the dry conditions there. The local-scale forced instability related to the island topography and sea/mountain breeze systems may be able to break up the trade inversion and increase rainfall over most of the islands. In Central America, intense rainfall is also probably due to the close location of the Pacific and South America ITCZ. From week4(-1) until week1(-1), the amount of rainfall remains broadly similar (compare Fig. $4 \mathrm{~h}-\mathrm{j}$ ). A decrease in daily rainfall is then observed between week1(-1) and week1 $(+1)$ (Fig. $4 \mathrm{k})$. The western side of Cuba and the northern part of Central America observe a decrease of more than $2 \mathrm{~mm}$ /day, while the eastern Caribbean only shows a decrease lower than $1 \mathrm{~mm} /$ day in agreement with (Fig. 2k ). At the same time, the rainfall amount increases over the Caribbean side of Central America suggesting a symmetric pattern similar to the one observed with a strong CLLJ. The decrease in rainfall thus persists two weeks after the transition date over the western part of the Caribbean Sea and Central America (Fig. 4(l)). Although the S2W shift is overall smoother over the Caribbean compare to the more abrupt W2S transition, the $\mathrm{S} 2 \mathrm{~W}$ transition date still represents a regional-scale change from wet-to-dry conditions over the Caribbean basin and Central America. 
W2S transition
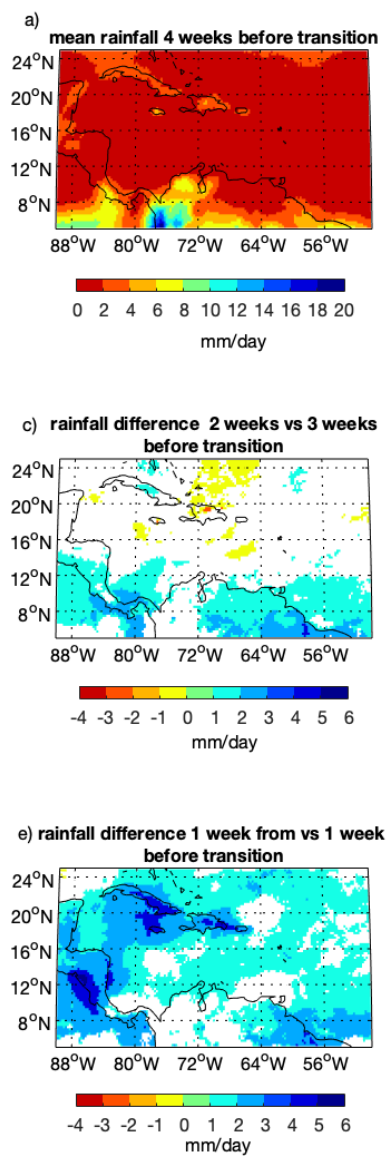
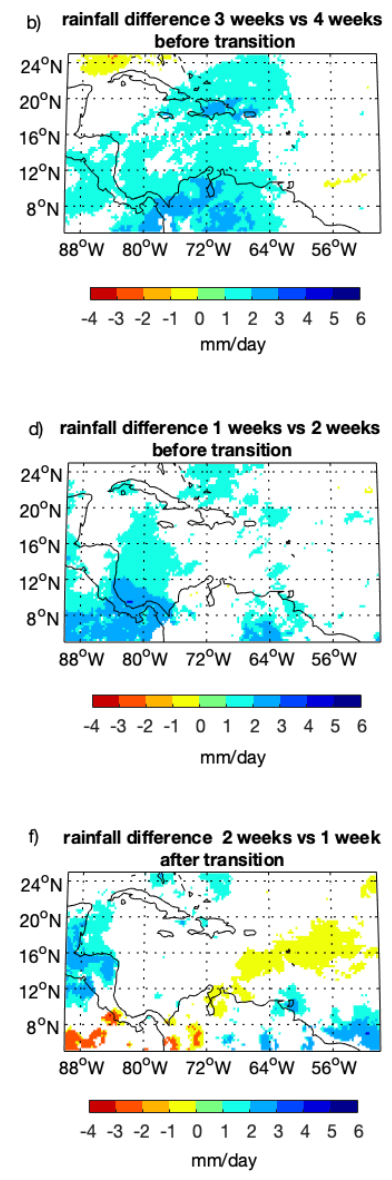

S2W transition
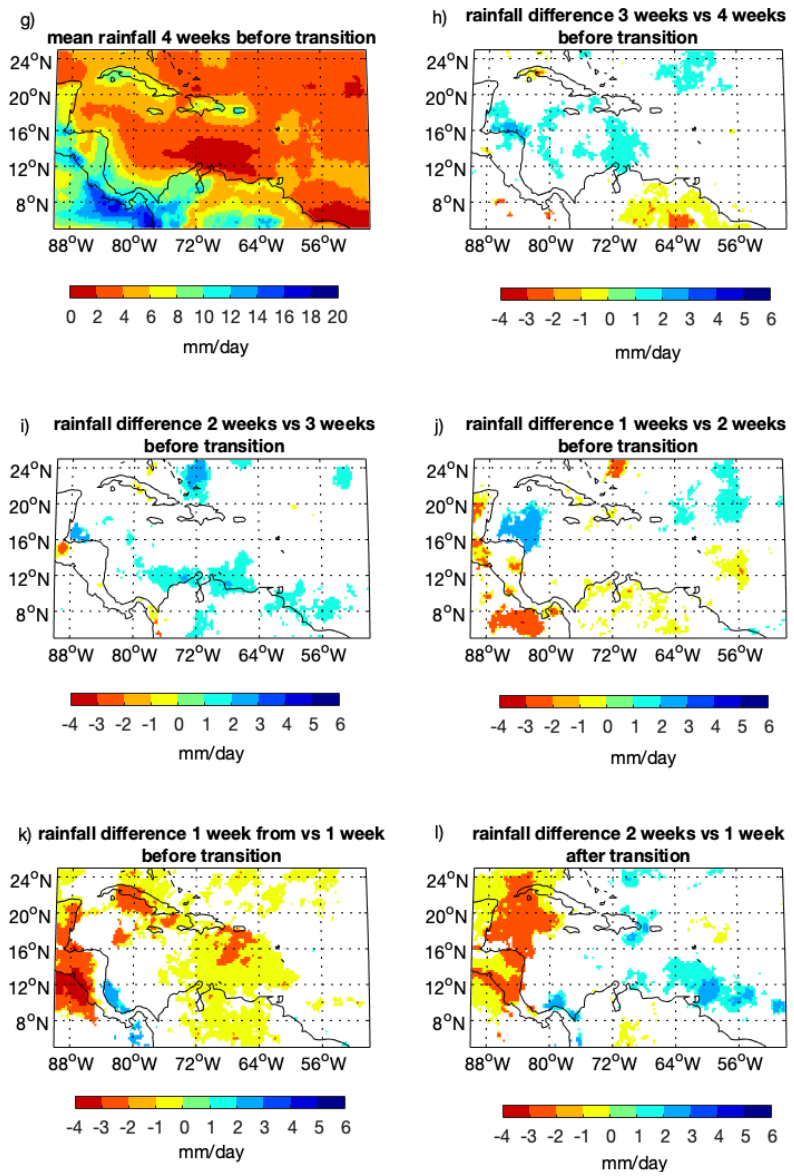

Fig. 4 Two left (right) panels correspond to the W2S (S2W) transition: (a),(g) average of rainfall (mm) over the Caribbean basin in the fourth week (week4(-1)) before the W2S (S2W) transition; (b),(h) difference between the amount of rainfall received on the third week (week3(-1)) before the transition minus the amount of rain in week4(-1); (c),(i) difference between the average amount of rainfall received on the second week (week2(-1)) before the transition minus the amount received during week3(-1); (d),(j) difference between the average amount of rainfall received on the first week (week1(-1)) before the transition minus the amount received during week2(-1); (e),(k) difference between the average amount of rainfall received on the first week (week1(+1)) after the transition minus the amount in week1(-1); and (f),(l) difference between the average amount of rainfall received on the second week (week $2(+1)$ ) after the transition minus week $1(+1)$. Only the significant differences are shown based on a Monte Carlo test at level $95 \%$. Both rainfall and rainfall differences are in mm/day.

3 Fig. 5 a confirms the sudden rainfall change around the W2S transition date observed in Fig. 3. Indeed CarRC shows an increase of $3 \mathrm{~mm} /$ day prior vs. after the date of transition while Fig. (4h-j) the average only increases from $2 \mathrm{~mm} /$ day to more than $3 \mathrm{~mm} /$ day in (Fig. 5(a)). At the time of the W2S transition, the amount of rainfall for both CarRC and CarRP is close to the average annual amount of rainfall with $4.1 \mathrm{~mm} /$ day and $2.4 \mathrm{~mm} /$ day respectively. CarPW starts to increase 60 days before the W2S transition date, but a sharp increase is observed from the W2S transition date, when it reaches more than $37 \mathrm{~kg} / \mathrm{m}^{2}$ (which is a value close to the annual average of $\left.37.6 \mathrm{~kg} / \mathrm{m}^{2}\right)$ to 20 days after when it reaches a maximum of $41 \mathrm{~kg} / \mathrm{m}^{2}$ (Fig. 5 (b)). This suggests an increased rate in the moisture supply over the domain around the W2S transition date and a potential minimum level of precipitable water required to trigger regional-scale rainfall. The decrease in the amount of daily rainfall over the Amazon starts 10 to 20 days before the W2S transition date but does not seems to be a potential indicator of a shift in the rainfall regime over the Caribbean basin (correlation between W2S and Amazon rainfall at the time of the transition is around 0.3, see Fig. 6).

None of the SST indices shows a rapid warming around the W2S transition date (Fig. 5d). Their gradual warming is likely associated with the seasonal increase of the amount of incoming solar radiation. Nevertheless, CARS, PAC and GMEX show temperature 
above $26.5^{\circ} \mathrm{C}$ at the time of the $\mathrm{W} 2 \mathrm{~S}$ transition, a condition favorable to deep convection, while the EEP temperature cools down to $26^{\circ} \mathrm{C}$ leading to a $1^{\circ} \mathrm{C}$ gradient between EEP and the CARS (Fig. 5 d). In summary, the changes in SST around the W2S transition date are broadly gradual and may not be the main (or unique) trigger of the abrupt change in the rainfall, except perhaps for a threshold effect related to SST crossing the $26.5^{\circ} \mathrm{C}-27^{\circ} \mathrm{C}$ temperature possibly combined with a certain amount of precipitable water around $36 \mathrm{~kg} / \mathrm{m}^{2}$. Prior to the W2S transition date, neither the CLLJ or the CJ are showing a significant decrease or increase. However, the intensity of the CLLJ decreases rapidly from the W2S transition date up to ten days after when it reaches its minimum annual value (Figs. 5e,f). On the other hand, the CJ veers to become eastward at the time of the W2S transition date suggesting a shift in the atmospheric circulation at that time. All the elements required for deep convection are thus present at the date of W2S transition (i.e., an SST greater than $27^{\circ} \mathrm{C}$, precipitable water amount more than $37 \mathrm{~kg} / \mathrm{m}^{2}$, and a weak CLLJ). However, none of the variables exhibits the abrupt change noticed in local-scale rainfall around the W2S transition date (Fig. 3). At that time, all of the variables show an average annual value suggesting that the atmospheric and oceanic states reach a pseudo-balance (i.e., an average state of the system) with all the necessary conditions for convection being present).

At the date of the $\mathrm{S} 2 \mathrm{~W}$ transition (Fig. $5 \mathrm{~s}-\mathrm{i}$ ), CarRC decreases more than $6 \mathrm{~mm} /$ day to $4 \mathrm{~mm} /$ day, and CarPR decreases $5 \mathrm{~mm} /$ day to less than $4 \mathrm{~mm} /$ day. CarPW also decreases, namely from $42 \mathrm{~kg} / \mathrm{m}^{2}$ to less than $40 \mathrm{~kg} / \mathrm{m}^{2}$ nine days after the $\mathrm{S} 2 \mathrm{~W}$ transition. On the other hand, SST indices are still warmer than 27$28^{\circ} \mathrm{C}$ after the $\mathrm{S} 2 \mathrm{~W}$ transition date. Unlike the W2S transition, the SST indices still all have values above their annual average at the time of the S2W transition. The rainfall amount and precipitable water are still decreasing after the S2W transition date. It is possible that the Atlantic subtropical high has started its southward shift thus potentially inhibiting the deep convection despite ocean temperature warmer than $27^{\circ} \mathrm{C}$ (Fig. 5j). The CLLJ strengthens from $5 \mathrm{~m} / \mathrm{s}$ to $7 \mathrm{~m} / \mathrm{s}$ around the $\mathrm{S} 2 \mathrm{~W}$ transition date, along with the increase of rainfall over the Caribbean side of Central America (Fig. 4k), and then further strengthens toward a maximum forty days after the S2W transition (Fig. 5k). The CJ still blows eastward but weakens after the S2W transition date (Fig. 51). All these features indicate a clear change, even if it is smoother than around the W2S transition, in the atmospheric circulation at the time of the S2W transition, while oceanic changes are rather limited. These results suggest that despite the warm surface ocean, others factors could slowly inhibit the rainfall, such as the increase of the CLLJ (and its related shear) potentially linked to a increase of pressure gradient between Azores/Bermuda high and low pressure located over South America.

The correlations between the 31-day moving average indices and the interannual variations of the W2S transition dates are significant for the CarRC, CarRP and CarPW indices at the time of or just before it (Fig. 6. Fig. 6 also shows significant, albeit weak, correlations (i.e., -0.3) between the W2S transition date and the CLLJ and CJ speed around the time of the transition. Therefore an earlier (later) transition is associated, as expected, with a higher (lower) amount of rainfall and precipitable water and, with a weaker (stronger) CLLJ and a westward (eastward) anomaly of the CJ. The correlations between the W2S transition date with the antecedent SST indices are not significant, suggesting that the interannual variations of the SST are weakly influencing the date of transition in boreal spring.

The correlations between S2W transition and the rainfall and precipitable water suggest that when the transition occurs earlier (resp., later), the amount of rainfall and precipitable water are logically lower (resp., higher) than normal (here, $r=0.6$ ). Fig. 6 also indicates that an earlier (resp., later) S2W shift tends to be preceded and accompanied by a cooler (resp. warmer) CARS and GMEX and a warmer (resp., cooler) EEP even if the correlations are mostly around 0.3-0.4, suggesting a weak to moderate seasonal predictability of S2W transitions associated with the boundary forcing of regional-scale SST. A westward (eastward) and stronger (weaker) CJ and a stronger CLLJ are also associated to an early (resp.,late) S2W transition with significant correlation at 0.3 at the time of the transition. It seems that the CJ anomaly related to the S2W transition is rather persistent during the whole rainy season.

\section{Predictability of the W2S Transition Dates}

Fig. 7 a shows the skill (i.e., the correlation between the average W2S transition date in ECMWF and the observed one in the NCEP+ERA1 scenario using the same parameterization) vs. the initialization date. The skill is close to zero until April 19, then suddenly increases to $0.5-0.6$ around April 24-25 and then stays at a constant level around 0.7 until May 10 close to the mean observed average W2S transition, for the best combinations (i.e., requests \#1 and \#7). The lack of any significant skill more than 3 weeks before the mean observed $\mathrm{W} 2 \mathrm{~S}$ transition date for all requests is fully consistent 
W2S transition
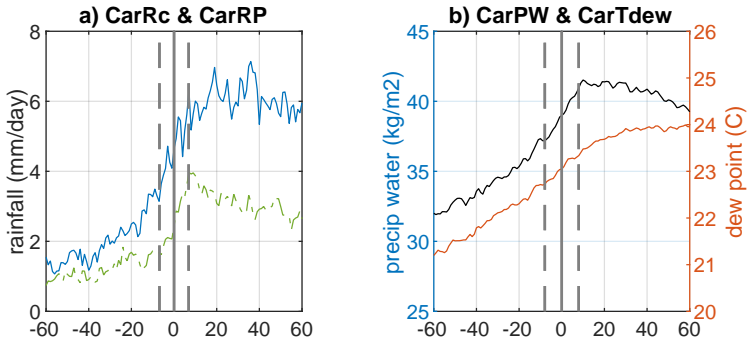

S2W transition
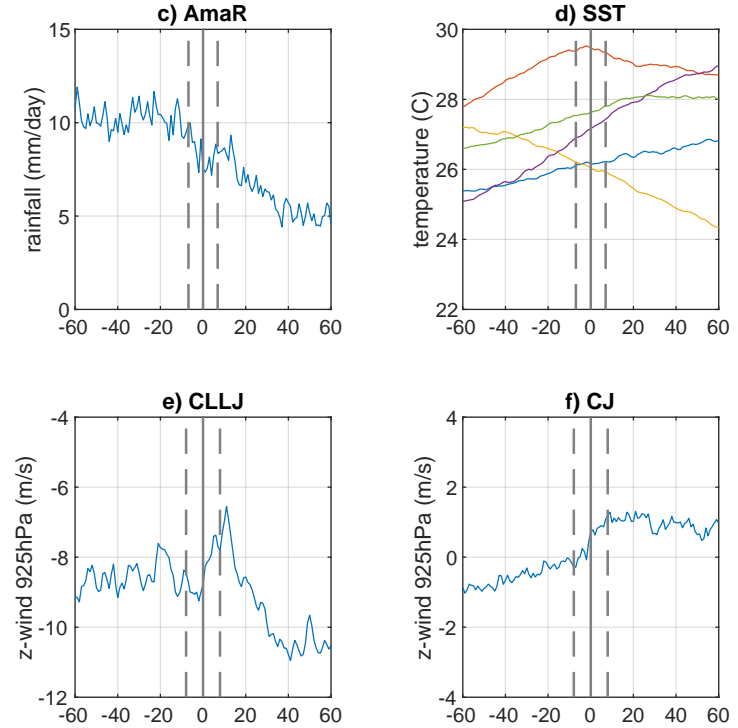
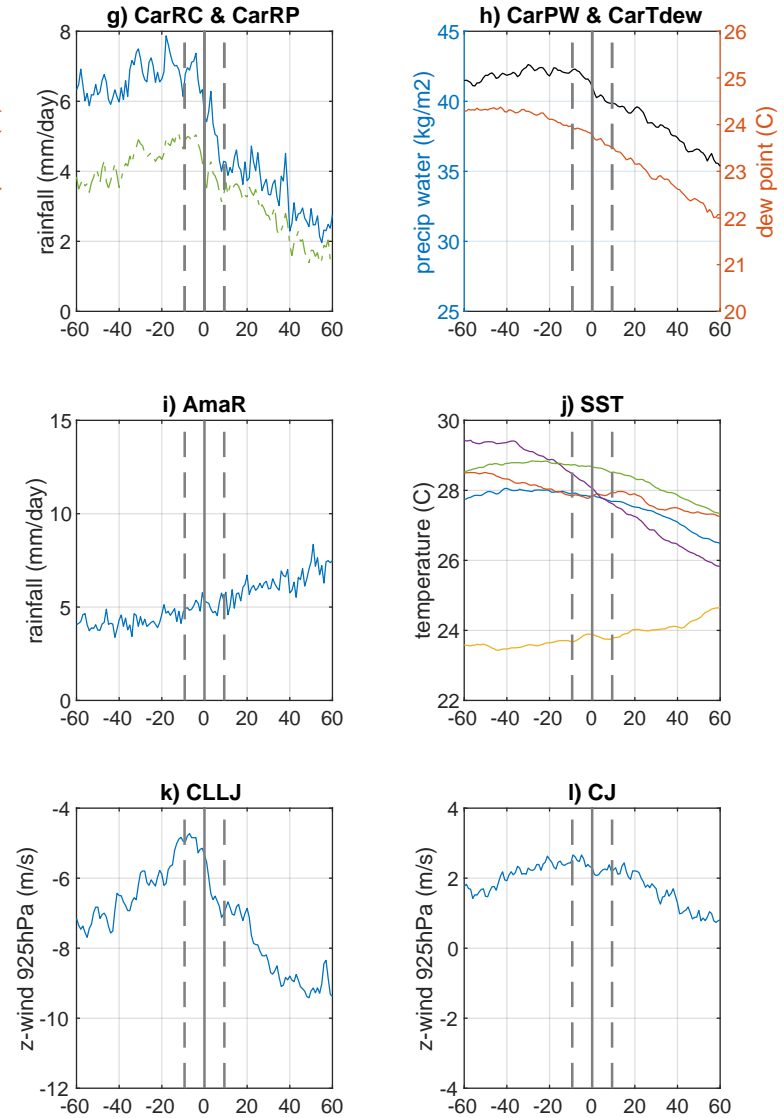

Fig. 5 Average of the indices 60 days before and after the transition date denoted by zero on the x-axis. Indices for the W2S transition (a)-(f) and the S2W transition (g)-(l). (a),(g) rainfall CarRC (blue line), CarRP (green line) $\left(10^{\circ} \mathrm{N}-25^{\circ} \mathrm{N}, 90^{\circ} \mathrm{W}-\right.$ $\left.50^{\circ} \mathrm{W}\right)$, and $(\mathrm{b}),(\mathrm{h}) \mathrm{AmaR}\left(1^{\circ} \mathrm{S}-5^{\circ} \mathrm{S}, 75^{\circ} \mathrm{W}-50^{\circ} \mathrm{W}\right)$ in mm/day; (c), (i) precipitable water $(\mathrm{CarPW})\left(10^{\circ} \mathrm{N}-25^{\circ} \mathrm{N}, 80^{\circ} \mathrm{W}-60^{\circ} \mathrm{W}\right)$ in $\mathrm{kg} / \mathrm{m}^{2}$; (d), (j) SST over PAC (red line) $\left(7^{\circ} \mathrm{N}-16^{\circ} \mathrm{N}, 110^{\circ} \mathrm{W}-85^{\circ} \mathrm{W}\right)$, EEP (yellow line) $\left(5^{\circ} \mathrm{S}-5^{\circ} \mathrm{N}, 110^{\circ} \mathrm{W}-80^{\circ} \mathrm{W}\right)$, TNA (blue line) $\left(9^{\circ} \mathrm{N}-18^{\circ} \mathrm{N}, 80^{\circ} \mathrm{W}-60^{\circ} \mathrm{W}\right)$, GMEX (purple line) $\left(18^{\circ} \mathrm{N}-25^{\circ} \mathrm{N}, 95^{\circ} \mathrm{W}-80^{\circ} \mathrm{W}\right)$, and CarS (green line) $\left(9^{\circ} \mathrm{N}-18^{\circ} \mathrm{N}, 85^{\circ} \mathrm{W}-\right.$ $\left.60^{\circ} \mathrm{W}\right)$, in degree Celsius; (e),(k) CLLJ $\left(10^{\circ} \mathrm{N}-17.5^{\circ} \mathrm{N}, 65^{\circ} \mathrm{W}-80^{\circ} \mathrm{W}\right)$; and (f), (l) CJ $\left(5^{\circ} \mathrm{S}-7^{\circ} \mathrm{N}, 85^{\circ} \mathrm{W}-75^{\circ} \mathrm{W}\right)$ in $\mathrm{m} / \mathrm{s}$. The zero (vertical line) indicate the date of transition and the dotted lines represent $\pm 1 \mathrm{sd}$.

with the lack of sustained significant relationships between the observed transition dates and the SST indices shown in Fig. 6. This is also fully consistent with the weak variance explained by the logistic hindcast model of WT occurrence with SST indices at the start of the rainy season in Moron, Gouirand, and Taylor (2015). On the contrary, the sudden increase of skill concentrated in one week, between April 19 and April 26, suggests the main implication of an atmospheric process, possibly superimposed on the mean annual cycle. The lower three panels of Fig. 7 show the observed and forecast transition date using the parametrization \#7 for three starting dates, one (April 19) without any skill (Fig. 7b), and two others one (Fig. 7f) and two weeks (Fig. 7d) thereafter.

The issue raised by Fig. 7 is the nature of the atmospheric process(es) involved in the skill's increase after
mid-April. This is explored in Fig. 8. We extracted the 76 cases (out of a total 220 forecasts of transition date) where the average W2S transition date is accurately predicted on April 26 (with a tolerance of \pm 2 days). Then, the sequences of predicted daily WTs before the corresponding average W2S transition dates are keyed to the simulated average W2S transition dates (Fig. 8a). This is compared with the climatological CDF, that is the full set of daily sequence of WTs from April 26 to the simulated (right or wrong) average W2S transition date (Fig. 8p). Both panels are rather noisy with the 8 WTs usually observed before the average W2S transition dates. Some differences are visible between the successful prediction and the climatological CDF, as for example the positive frequency of WT 3 (which is a "dry" WT over the middle Caribbean basin (Moron, Gouirand, and Taylor, 2015) in the 5 to 1 day before the 
W2S transition
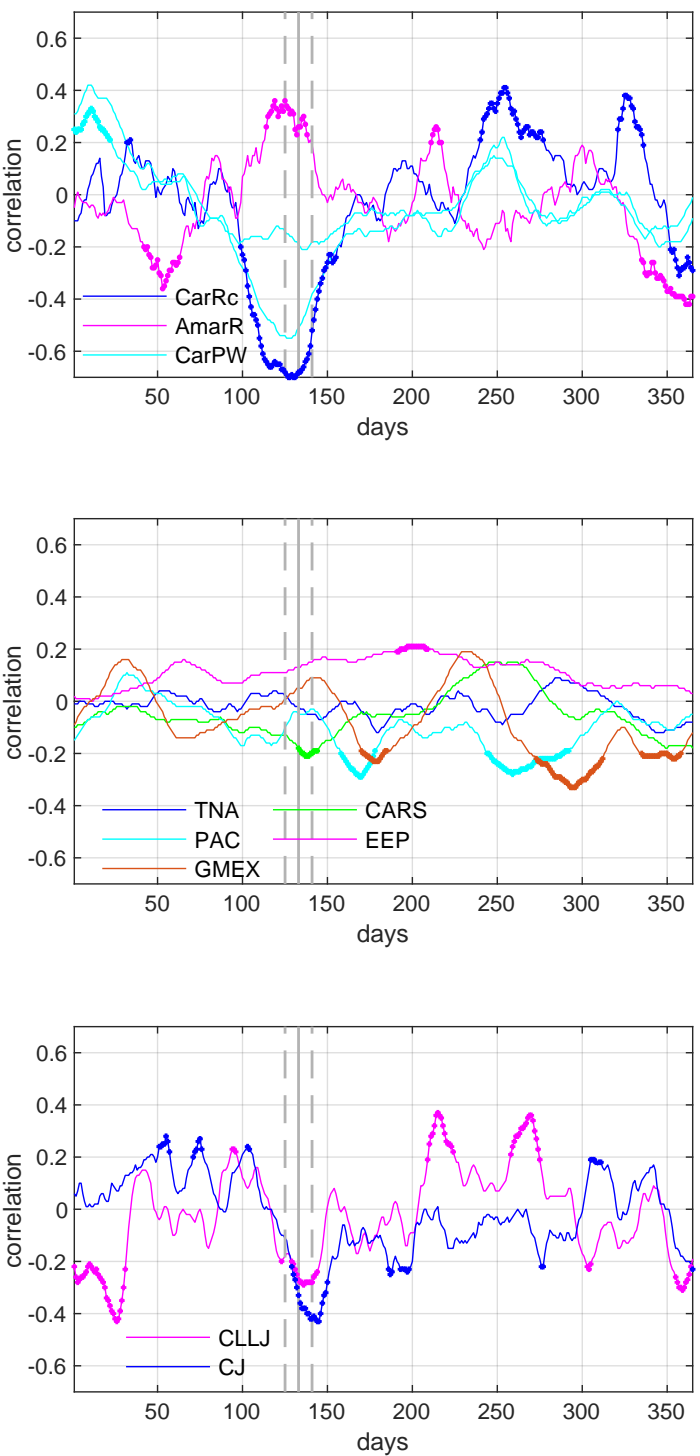

S2W transition
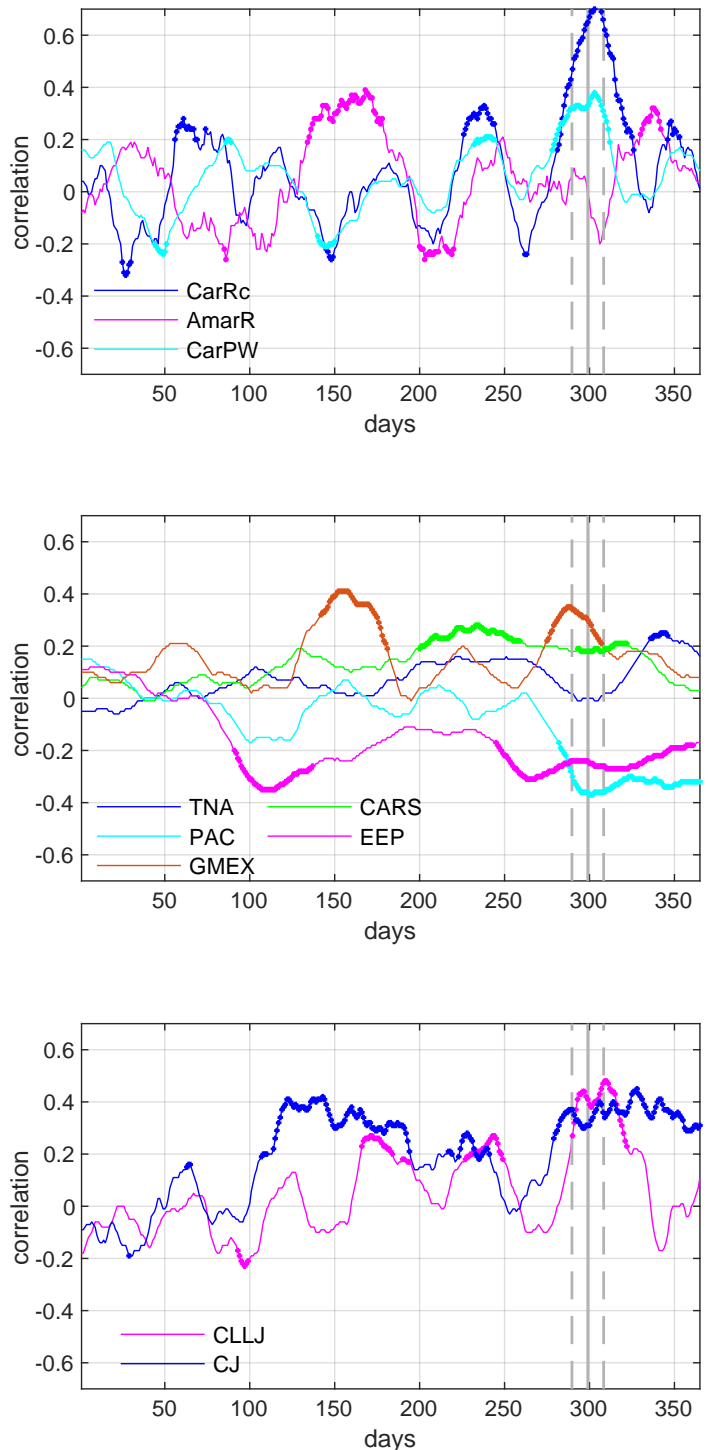

Fig. 6 Correlation between the 31-day moving average indices and the average W2S and S2W transition date for the 19822017 period. W2S (S2W) located on the left (right) panel. Top panels: W2S (S2W) vs. CarRC (blue), AmaR (pink) and CarPW (cyan); middle panels: W2S (S2W) vs. SST indices for CARS (green), PAC (cyan), EEP (pink), TNA (blue) and GMEX (orange); bottom panel: W2S (S2W) vs. 925hPa zonal wind CLLJ (pink) and CJ (blue). The dots mark significant correlation at $90 \%$ level according to Monte Carlo test. The vertical line represents the average date of transition and the vertical dotted lines represent \pm 1 sd.

1 successful average W2S transition date, but no obvious WT sequence is observed. It suggests that successful transition is not related to either a single atmospheric sequence or a single or few dominant sustained WTs. In other words, the transition between wintertime (i.e., WT 1-3 and 7-8) and summertime (i.e., WT 4-6) atmospheric mode, revealed by the W2S transition date, is barely associated with a specific transition amongst the WTs.
The temporal modulation of the intensity of the predictability is further explored on Fig. 9. The predictability of the regional-scale atmosphere is analyzed from two complementary points of view. First a "deterministic" error (Fig. 9a) is estimated through the root mean square error (RMSE) of zonal and meridional components of $925 \mathrm{hPa}$ winds between the predictions and the observations (= initializations) from the 13 starting dates (from March 29, approximately 1.5 months before the observed average W2S transition 
a) Skill of WT-transition date winter-to-summer

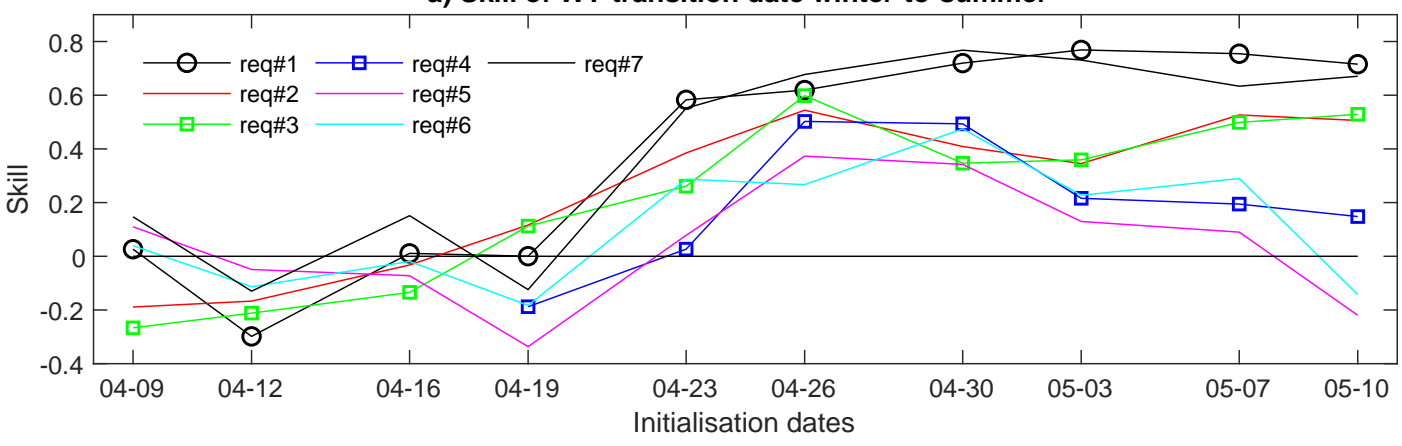

b) Onset observed and forecast from April 19 based on req\#7

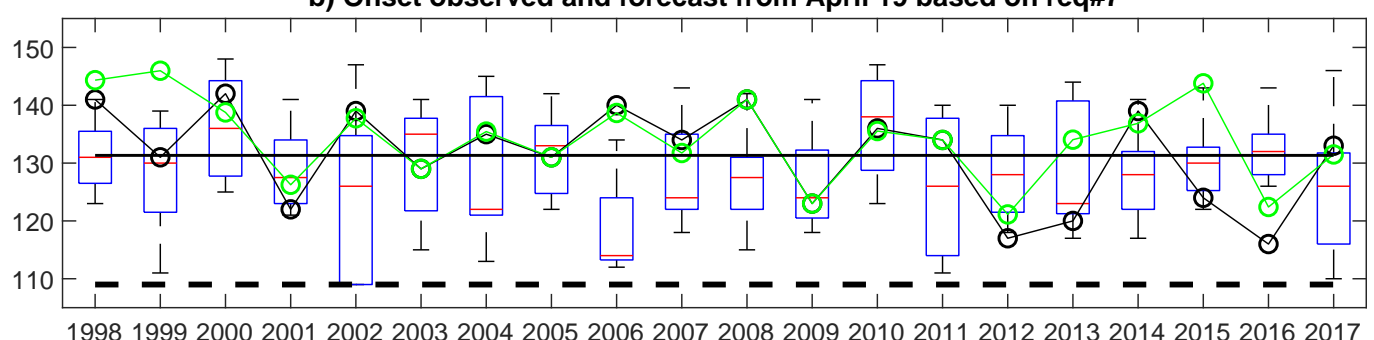

c) Onset observed and forecast from April 26 based on req\#7

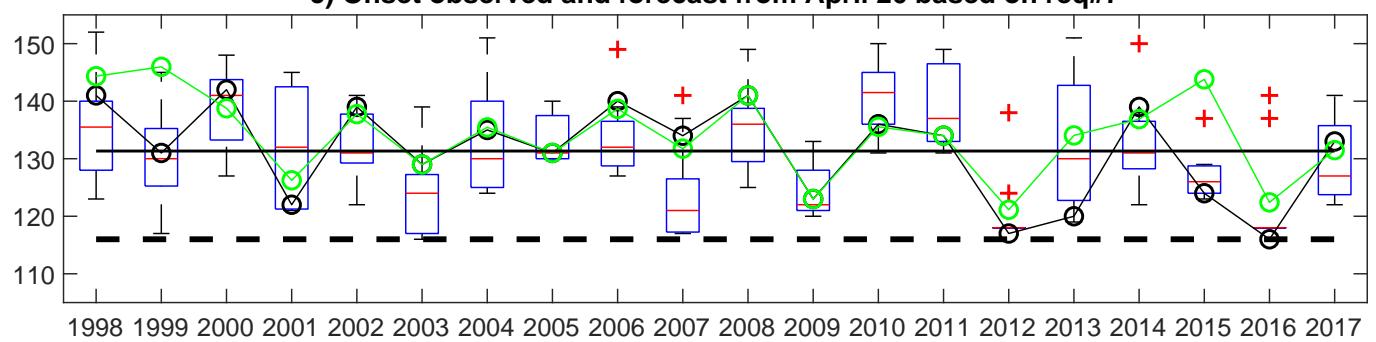

d) Onset observed and forecast from May 3 based on req\#7

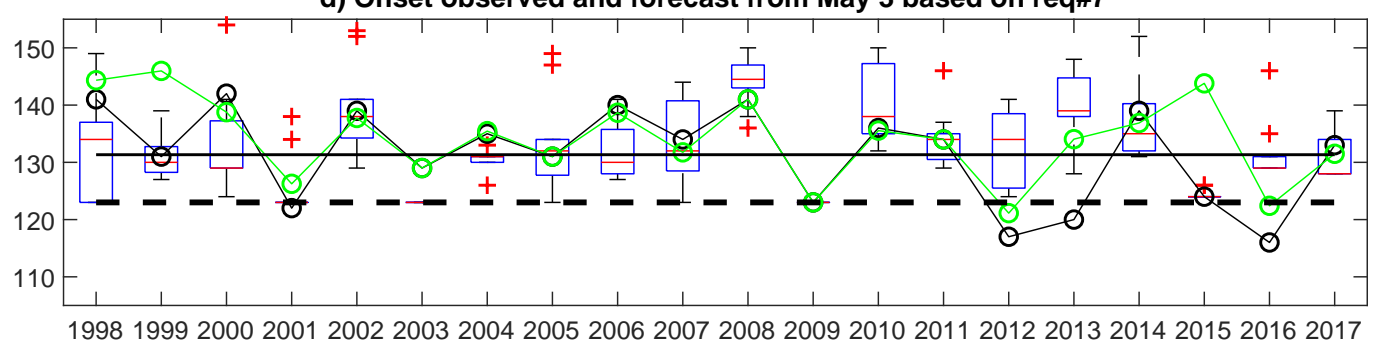

Fig. 7 (a) Skill of WT-transition in a 11-run ensemble of the ECMWF model vs. the initialization date. The x-axis shows the initialization dates and the different curves shows seven parametrizations of WT-transition (detailed in text). The observed WT-transition date occurring before the initialization dates are not used to compute the correlations between observed and the ensemble mean WT-transition. (b)-(d) Time series of observed transition dates based on the average of the 144 requests from NCEP+ERA1 (green circle), based on request \#7 in the ECWMF (black circle) and the ECMWF (box plot with red line as median, upper and lower limit and upper and lower quartiles, red crosses as outliers) WT-transition for 3 initialization dates (April 19, April 26 and May 3). The WT-transition is defined using request \#7 which uses the following criterion: 5 days of summer WTs not followed by 2 days of winter WTs in following 4 days after the last summer WT. The dashed horizontal line is the initialisation date and the full horizontal line is the mean of observed WT-transition. 
(a) ECMWF runs for skillful years (init $=$ April 26)

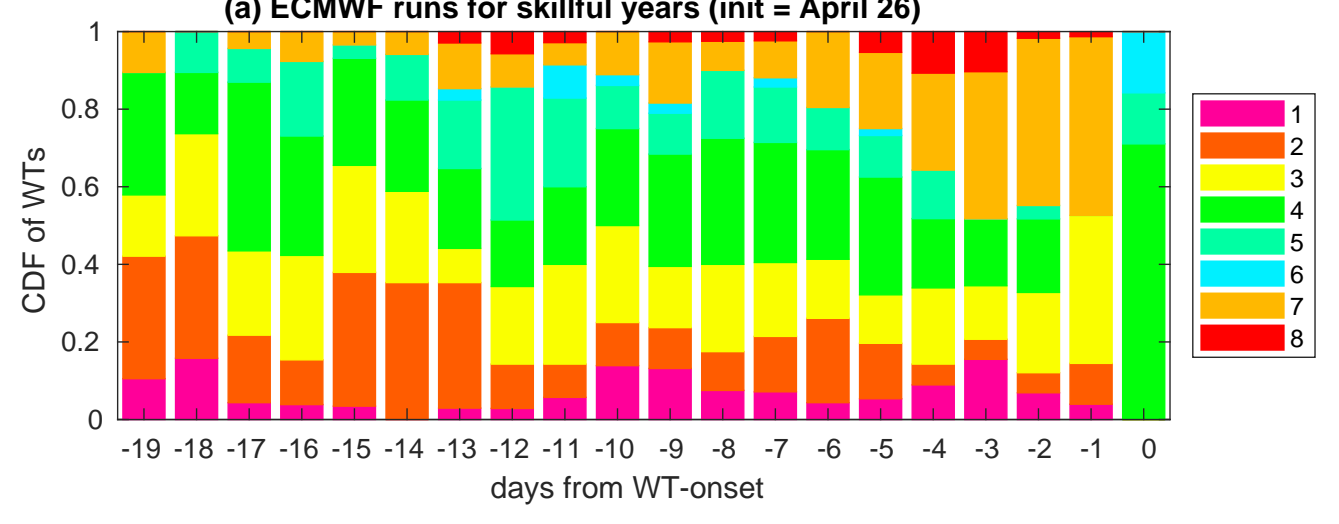

(b) ECMWF runs WTs for all years (init = April 26)

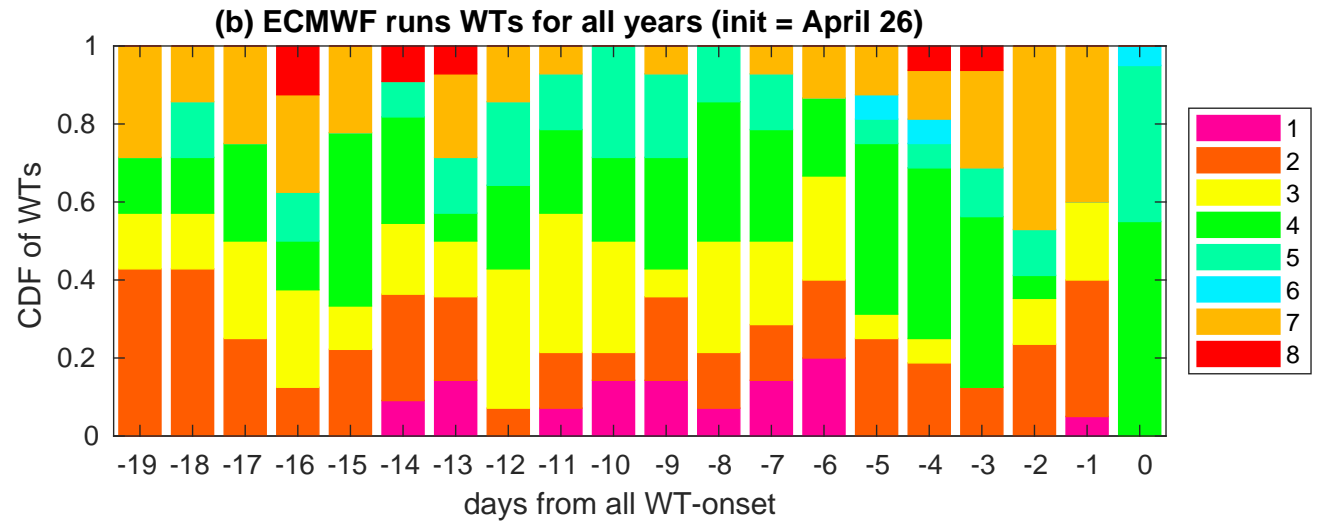

Fig. 8 (a) CDF of the ECMWF WT-transition occurring before the WT-transition (=0 in the abscissa) for the 76 run-years when the observed WT-onset is accurately predicted (with a tolerance of \pm 2 days) from April 26 . The WT-transition is defined using the following parametrization ( 5 days of summer WTs not followed by 2 days of winter WTs in following 4 days after the last summer WT). (b) Same as (a) except for the whole set of 220 run-year.

date). For example, RMSE between the 5-day predictions from March 29 and the observed wind on April 2 is computed. This error is computed separately on each run and then averaged across years and runs. A second error is simply the standard deviations amongst the 11 runs across the same starting dates and lead times as before (Fig. 9b). This spread refers simply to the amount of variance due to initialization. Both errors are different empirical estimates of the same variance, i.e., the one related to chaotic unpredictable atmospheric dynamics. As expected, the error increases with lead time. It is also clear that errors at a lead time of $4-5$ and 9 days are rather constant across the starting dates, while the errors for a lead time between 2 and 3 weeks clearly decrease from late March to early May. In other words, the regional-scale atmosphere becomes more and more predictable beyond the synoptic time scale as time goes by in April. It probably involves multiple "slow" coupled convective equatorial waves and any other processes slower than roughly 1 week.

In summary, Figs. 89 suggest that the interannual variations of the W2S transition date are mostly forced by multiple atmospheric processes. In other words, there are multiple ways to switch in few days/weeks from one to the other phase of the annual cycle and that the useful predictability (usually defined by a correlation between observation and forecast $\geq 0.3-0.4$ ) is limited to $2-3$ weeks at most and related to any atmospheric process.

\section{Discussion and Conclusion}

The W2S and S2W regional-scale transition dates are identified from the same approach than the one used to determine the onset of rainfall based on cumulative amount of rainfall over a certain number of days or pentad. The cumulative daily amount of rainfall is substituted by a sequence of summer and winter WTs. Additionally, conditional probability, considering equiprobable combinations having a chance of $40-60 \%$ to occur, have been used to select the requests, thus reducing the subjectivity of the selection. The comparison of the results obtained from the four scenarios using 
(a) Deterministic error (lead vs init)

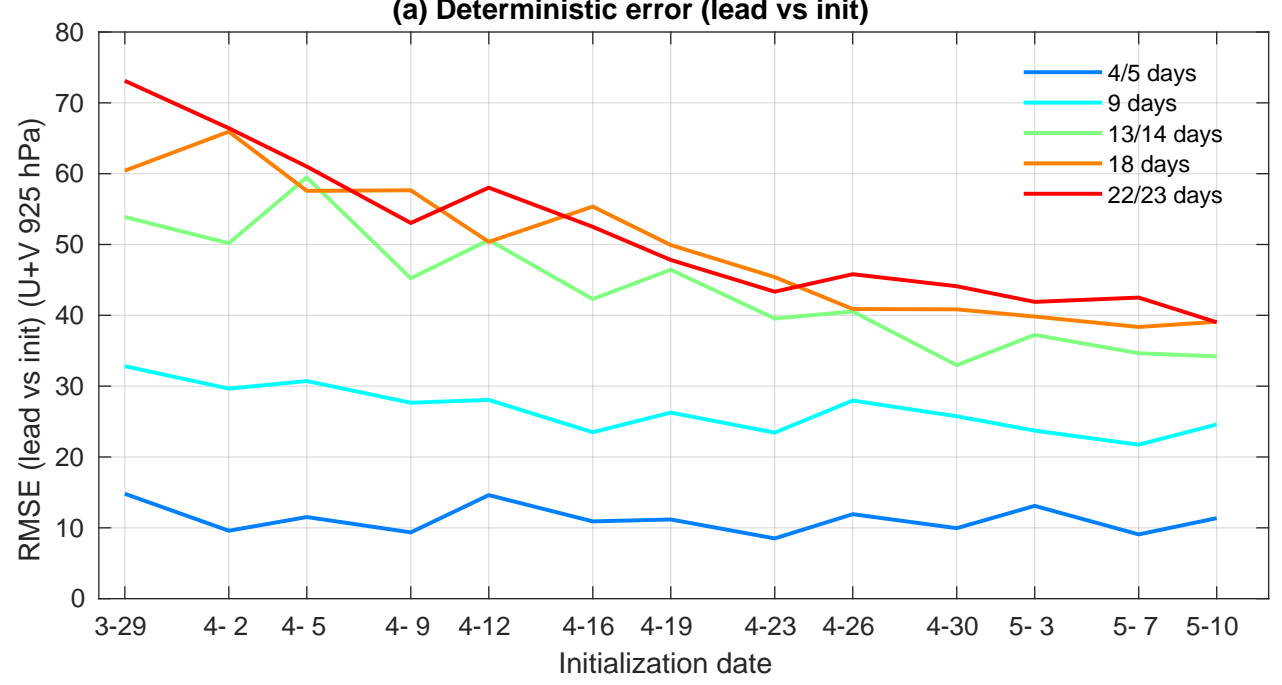

(b) Noise (inter-run sd)

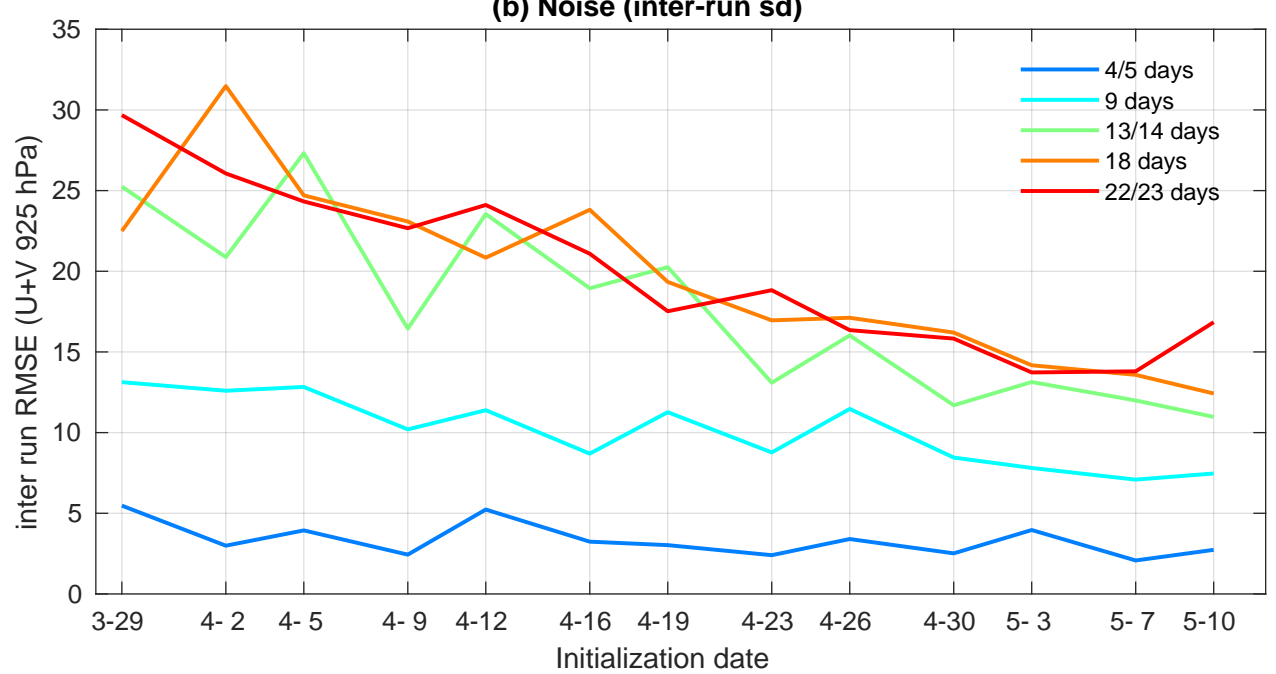

Fig. 9 (a) Deterministic error (= RMSE) between predicted fields and initial state for successive initialization dates indicated in the abscissa and 5 lead time shown as colored curves. The RMSE is computed on U and V components at $925 \mathrm{hPa}$ of each run and each year and then averaged across the 11 runs and the 20 years; (b) inter-run error amongst the 11 runs for successive initialization dates indicated in the abscissa and 5 lead time shown as colored curves. It is computed as the standard deviations amongst the 11 runs averaged across the years.

1 two different reanalyses (NCEP, ERA, NCEP+ERA and NCEP+ERA1) demonstrates that the results were not too sensitive to the requests or to the reanalyses. It also highlights the robustness of the W2S and S2W transition dates obtained from the regional-scale WTs compared to a transition date obtained with a threshold of local-scale rainfall. Indeed, Kousky (1988) suggested previously that the onset of the rainy season over the Caribbean cannot be determined from the OLR alone, due to a lack of a clear cut between the dry and the wet season. Marengo et al (2001) also mentioned a dependence of the onset over the Brazilian Amazon region to the threshold of rainfall used to identify it. In consequence, the WTs approach appears as an alternative method to determine a seasonal transition at regional-scale, especially when no abrupt change in rainfall amount exists, as it is usually observed in stricto-sensu monsoon climate.

The results show that the average date of the W2S and S2W regional-scale seasonal transitions can indeed 
be estimated from the switch between wintertime and summertime regional-scale WTs (and vice versa). The W2S transition date is near-synchronous with a rapid regional-scale increase in the daily amount of rainfall around early May, while the S2W transition is overall smoother around late October and less clearly keyed to an abrupt decrease of local-scale rainfall, especially over the south and east of the domain. Therefore, the average W2S transition date (less clearly for the S2W transition date) constitutes an indirect indicator of the average shift from dry-to-wet (wet-to-dry) season over the Caribbean basin and Central America. The average W2S date, over the 1979-2017 period, occurs on May 13 plus or minus 9 days, in agreement with Mapes et al (2004) that detected an onset date of the rainfall around May 1st and May 10th. The S2W date occurs, on October 26 plus or minus 12 days. Thus, the "summertime" atmospheric regime (from a WT point of view) or regional-scale wet season lasts 165 days on average and no change in the length of the wet season has been noticed since 1979. The absence of significant correlation between the W2S and S2W and between $\mathrm{S} 2 \mathrm{~W}(0)$ and $\mathrm{W} 2 \mathrm{~S}(+1)$ transition dates suggests that the seasonal shifts are independent and influenced by different forcings. This is in agreement with Taylor et al (2002) and Taylor et al (2011) who have shown that the beginning of the rainy season is more influenced by the Atlantic Ocean while the end of the rainy season is more affected by the SST over the East Equatorial Pacific.

Moreover, the analysis of the SST indices also highlights a main difference between both W2S and S2W transitions. Indeed, there are no significant correlations between antecedent variations of SST over the tropical Atlantic and Eastern Pacific and the W2S transition (and also the near-zero predictability beyond a 15-20 day lead time in the S2S exercise), while the interannual variations of $\mathrm{S} 2 \mathrm{~W}$ is preceded by significant, albeit weak, SSTA in both basins. The first result is somewhat in disagreement with other studies showing the influence of the tropical North Atlantic on the early Caribbean rainfall (Chen and Taylor, 2002, Giannini et al, 2000, Gouirand et al, 2016; Taylor et al, 2002). Nevertheless, these past studies shown a link between the Atlantic and the amount of rainfall during the early rainy season but that does not imply that the tropical North Atlantic is modulating the timing of the shift between seasons. In contrast, the influence of the Eastern Pacific on the late rainy season was already shown by Taylor et al (2002, 2011); Moron, Gouirand, and Taylor (2015). This study thus adds that the Eastern Pacific could modulate the timing of the end of late rainy season. Hence, a drier and early (resp., wetter and delayed) ending of the late rainy season seems to be associated with a warmer (resp., colder) EEP added to an anomalously cold (resp. warm) TNA, CARS and GMEX.

The fluctuations of both the CJ and CLLJ seem to also play a role in the S2W transition. Several studies have shown a relationships between the CLLJ and the Caribbean rainfall, a stronger CLLJ being associated with lower rainfall except on the Caribbean side of Costa Rica (Wang and Lee, 2007). The relationships between CLLJ and rainfall were mainly studied in regard to the mid-summer drought but not with respect to the W2S and $\mathrm{S} 2 \mathrm{~W}$ transitions. Note that at the time of the W2S transition, the CLLJ weakens (Fig. 5), then slightly strengthens in July at the time of the mid-summer drought (Curtis and Gamble, 2008; Angeles et al., 2010, Cook and Vizy, 2010), weakens again in August-September before reaching its maximum around and after the $\mathrm{S} 2 \mathrm{~W}$ transition Cook and Vizy, 2010).

In consequence, the mean characteristics around both the W2S and the S2W transition dates reveal a major asymmetry in the annual cycle around the Caribbean basin. The regional-scale W2S date is locked with an abrupt increase in the daily amount of rainfall starting from the southern part of Central America before propagating further north and east a few days later in agreement with Mapes et al (2004) and Moron, Frelat et al (2015), while the S2W date is far smoother. The rapid increase of the amount of rainfall during the W2S transition could be dependent on a tipping point (or a combination of) in any of the oceanic or atmospheric variables such as the SST threshold for the convection, a needed amount of precipitable water in the atmosphere, a weaker CLLJ or a combo of several oceanic and atmospheric factors. The W2S transition date occurs when the general atmospheric circulation is close to its annual average suggesting that, in boreal spring, the climate seems to be in "conditional stability". Therefore, any atmospheric processes such as easterly waves, troughs, cold surge or the Madden Julian oscillation could destabilize the system and potentially trigger the W2S transition and thus the start of the regional-scale summer (and main rainy) season. The S2W transition in boreal fall presents a slightly larger interannual variability and the shift is not synchronous to a regional-scale decrease of rainfall everywhere over the whole Caribbean basin and Central America. Indeed, the southern part of the Caribbean basin does not show a sharp decrease in rainfall at the time of the S2W transition while the northern part of the basin shows a decrease in the daily amount of rainfall synchronous with it.

Additionally, the analysis of the predictability of the W2S transition dates have been investigated using ret- 
rospective forecast of an 11-run ensemble of ECWMF S2S model. The skill of the model is nil up to April 19th and increases rapidly after this date. This supports a null-to-weak forcing of the sea surface temperature, but also suggests a main influence of atmospheric processes, possibly superimposed on the mean annual cycle of solar radiation. Moreover, the analysis of the sequence of the WTs associated with successfully predicted average W2S date indicates that the transition is barely related to a specific sequence of the WTs in agreement with Moron, Gouirand, and Taylor (2015) showing that the WTs type were occurring randomly, i.e., with no preferential sequences. Furthermore, the approach, consisting in looking at (i) a "deterministic" error based on the RMSE of zonal and meridional components of $925 \mathrm{hPa}$ between the predictions and the initializations from the starting dates from early April, and (ii) at the error corresponding to the spread between the 11 run across the same starting dates and lead time, shows that the beyond the synoptic time scale when getting closer to the end of April and the beginning of May. This supports the idea that multiple atmospheric processes are forcing the W2S transition thus limiting its predictability to $2-3$ weeks at most, before the transition.

In conclusion, an approach using WTs could be used to indirectly determine a regional-scale seasonal shift in rainfall in regions where the change in rainfall amount is not consequent enough to be accurately captured by the agro-meteorological method. The method used in this study could also be applied to estimate the start and end of the mid-summer spell and to analyse the factors involved in the reduced amount of rainfall observed in the Caribbean basin and Central America in July. Ann NY Acad Sci 1146:153-188. DOI: 10.1196/annals.1446.012

Angeles ME, González JE, Ramírez-Beltrán ND, Tepley CA, Comarazamy DE (2010) Origins of the Caribbean rainfall bimodal behavior. J Geophys Res 115:D11106. DOI: 10.1029/2009jD012990 predictability of the regional-scale atmosphere increases
Ashby SA, Taylor MA, Chen AA (2005) Statistical models for predicting rainfall in the Caribbean. Theor Appl Climatol 82:65-80. DOI: 10.1007/s00704004-0118-8

Ashok K, Behera SK, Rao SA, Weng H, Yamagata T (2007), El Niño Modoki and its possible teleconnection. J Geophys Res 112:C11007. DOI: 10.1029/2006JC003798

Ashouri H, Hsu K, Sorooshian S, Braithwaite DK, Knapp KR, Cecil LD, Nelson BR, Prat OP (2015) PERSIANN-CDR: Daily precipitation climate data record from multisatellite observations for hydrological and climate studies. Bull Am Meteorol Soc 96:6983. DOI: 10.1175/BAMS-D-13-00068.1

Blume H (1974) The Caribbean Islands. Longman, London. ISBN: $978-0582481640$

Bombardi RJ, Moron V, Goodnight JS (2019) Detection, variability, and predictability of monsoon onset and withdrawal dates: A review. Int J Climatol, in press. DOI: 10.1002/joc.6264

Carlson TN, Prospero JM (1972) The largescale movement of Saharan air outbreaks over the northern equatorial Atlantic. J Appl Meteor 11:283-297. DOI: 10.1175/15200450(1972)011<0283:TLSMOS > 2.0.CO;2

Chadee XT, Clarke RM (2015) Daily near-surface large-scale atmospheric circulation patterns over the wider Caribbean. Clim Dyn 44:2927-2946. DOI: $10.1007 / \mathrm{s} 00382-015-2621-2$

Chen AA, Taylor MA (2002) Investigating the link between early season Caribbean rainfall and the El Niño +1 year. Int $\mathrm{J}$ Climatol 22:87-106. DOI: $10.1002 /$ joc.711

Cook KH, Vizy EK (2010) Hydrodynamics of the Caribbean low-level jet and its relationship to precipitation. J Clim 23:1477-1494. DOI: $10.1175 / 2009$ JCLI3210.1

Curtis S (2013) Daily precipitation distributions over the intra-Americas sea and their interannual variability. Atmósfera 26:243-259. DOI: 10.1016/S01876236(13)71074-9

Curtis S, Gamble DW (2008) Regional variations of the Caribbean mid-summer drought. Theor Appl Climatol 94:25-34. DOI: 10.1007/s00704-007-0342-0

Diday E, Simon JC (1976) Clustering analysis. In: Fu KS (ed) Digital Pattern Recognition. Communication and Cybernetics, vol 10. Springer, Berlin, pp 4794. DOI: $10.1007 / 978-3-642-96303-2 \_3$

Douglas MW, Maddox RA, Howard K, Reyes S (1993) The Mexican monsoon. J Clim 6:1665-1677. DOI: 10.1175/15200442(1993)006<1665:TMM > 2.0.CO;2 
Dunion JP (2011) Rewritting the climatology of the tropical North Atlantic and Caribbean sea atmosphere. J Clim 24:893-908. DOI: $10.1175 / 2010$ JCLI3496.1

Enfield DB (1996) Relationships of inter-american rainfall to tropical Atlantic and Pacific SST variability. Geophys Res Lett 23:3305-3308. DOI: 10.1029/96GL03231

Enfield DB, Alfaro EJ (1999) The dependence of Caribbean rainfall on the interaction of the tropical Atlantic and Pacific Oceans. I J Clim 12:2093-2103. DOI: 10.1175/15200442(1999)012<2093:TDOCRO > 2.0.CO;2

Enfield DB, Mayer DA (1997) Tropical Atlantic sea surface temperature variability and its relation to $\mathrm{El}$ Niño-Southern Oscillation. J Geophys Res 102:929945. DOI: $10.1029 / 96 J C 03296$

Funk CC, Peterson PJ, Landsfeld MF, Pedreros DH, Verdin JP, Rowland JD, Romero BE, Husak GJ, Michaelsen JC, Verdin AP (2014) A quasi-global precipitation time series for drought monitoring. U.S. Geological Survey Data Series 832, 4 pages. DOI: $10.3133 / \mathrm{ds} 832$

Gamble DW, Curtis S (2008) Caribbean precipitation: Review, model and prospect. Progress in Physical Geography: Earth and Environment 32:265-276. DOI: $10.1177 / 0309133308096027$

García-Serrano J, Cassou C, Douville H, Giannini A, Doblas-Reyes FJ (2017) Revisiting the ENSO teleconnection to the tropical North Atlantic. J Clim 30:6945-6957. DOI: 10.1175/JCLI-D-16-0641.1

Ghil M, Robertson AW (2002) "Waves" vs. "particles" in the atmosphere's phase space: A pathway to long-range forecasting? Proc Natl Acad Sci U.S.A 99:2493-2500. DOI: 10.1073/pnas.012580899

Giannini A, Chiang JCH, Cane MA, Kushnir Y, Seager R (2001) The ENSO teleconnection to the tropical Atlantic ocean: Contributions of the remote and local SSTs to rainfall variability in the tropical Americas. J Clim 14:4530-4544. DOI: 10.1175/15200442(2001)014<4530:TETTTT>2.0.CO;2

Giannini A, Kushnir Y, Cane MA (2000) Interannual variability of Caribbean rainfall, ENSO and the At-

lantic Ocean. J Clim 13:297-311. DOI: 10.1175/15200442(2000)013<0297:IVOCRE > 2.0.CO;2

Gloneck GFV, McCullagh P (1995) Multivariate logistic models. J Royal Stat Soc B57:533-546. DOI: 10.1111/j.2517-6161.1995.tb02046.x

Gonzlez M, Barros V and Doyle, M (2002) Relation between the onset and end of the South American summer monsoon and rainfall in subtropical South America. Climate Res 21:141-155. DOI: 10.3354/cr021141
Gouirand I, Jury MR, and Sing B (2012) An analysis of low- and high-frequency summer climate variability around the Caribbean Antilles. J Clim 25:3942-3952. DOI: $10.1175 /$ JCLI-D-11-00269.1

Gouirand I, Moron V (2003) Variability of the impact of El Niño-Southern Oscillation on sea-level pressure anomalies over the North Atlantic in January to March (1874-1996). Int J Climatol 23:1549-1566. DOI: $10.1002 /$ joc.963

Gouirand I, Moron V, Hu Z-Z, Jha B (2014) Influence of warm pool and cold tongue El Niños on the following Caribbean rainy season rainfall. Clim Dyn 42:919929. DOI: $10.1007 / \mathrm{s} 00382-013-1753-5$

Gu G, Adler RF (2006) Interannual rainfall variability in the tropical Atlantic region. J Geophys Res 111:D02106. DOI: 10.1029/2005JD005944

Guanche Y, Mínguez R, Méndez FJ (2014) Autoregressive logistic regression applied to atmospheric circulation patterns. Clim Dyn 42:537-552. DOI: $10.1007 / \mathrm{s} 00382-013-1690-3$

Herrera E, Ault T (2017) Insights from a new high-resolution drought atlas for the Caribbean spanning 1950-2016. J Clim 30:7801-7825. DOI: 10.1175/JCLI-D-16-0838.1

Herrera E, Magaña V, Caetano E (2014) Air-sea interactions and dynamical processes associated with the midsummer drought. Int J Climatol 35:1569-1578. DOI: 10.1002/joc.4077

Higgins RW, Yao Y, Wang XL (1997) Influence of the North American monsoon system on the U.S. summer precipitation regime. J Clim 10:2600-2622. DOI: $10.1175 / 1520-$ 0442(1997)010<2600:IOTNAM > 2.0.CO;2

Hu Z-Z, Kumar A, Huang B, Xue Y, Wang W, Jha B (2011) Persistent atmospheric and oceanic anomalies in the North Atlantic from summer 2009 to summer 2010. J Clim 24:5812-5830. DOI: $10.1175 / 2011$ JCLI4213.1

Huffman GJ, Adler RF, Boivin DT, Gu G (2009) Improving the global precipitation record: GPCP version 2.1. Geophys Res Lett 36:L17808. DOI: $10.1029 / 2009$ GL040000

Huffman GJ, Adler RF, Morissey MM, Boivin DT, Curtis S, Joyce R, MacGavock B, Susskind J (2001) Global precipitation at one-degree daily resolution from multisatellite observations. 口 J Hydrometeor 2:36-50. DOI: 10.1175/15257541(2001)002<0036:GPAODD > 2.0.CO;2

Inoue M, Handoh IC, Bigg GR (2002) Bimodal distribution of tropical cyclogenesis in the Caribbean: Characteristics and environmental factors. J Clim 15:2897-2905. DOI: 10.1175/15200442(2002)015<2897:BDOTCI $>2.0 . \mathrm{CO} ; 2$ 
Janicot S, Moron V, Fontaine B (1996) Sahel droughts and ENSO dynamics. Geophys Res Lett 23:515-518. DOI: 10.1029/96GL00246

Jury MR (2009) An intercomparison of observational, reanalysis, satellite, and coupled model data on mean rainfall in the Caribbean. J Hydrometeor 10:413-430. DOI: $10.1175 / 2008$ JHM1054.1

Jury MR, Malmgren BA, Winter A (2007) Subregional precipitation climate of the Caribbean and relationships with ENSO and NAO. J Geophys Res 112:D16107. DOI: 10.1029/2006JD007541

Kalnay E, Kanamitsu M, Kistler R, Collins W, Deaven D, Gandin L, Iredell M, Saha S, White G, Woollen J, Zhu Y, Chelliah M, Ebisuzaki W, Higgins W, Janowiak J, Mo KC, Ropelewski C, Wang J, Leetmaa A, Reynolds R, Jenne R, Joseph D (1996) The NCEP/NCAR 40-year reanalysis project. Bull Amer Meteor Soc 77:437-472. DOI: 10.1175/15200477(1996)077<0437:TNYRP >2.0.CO;2

Kanamitsu M, Ebisuzaki W, Woollen J, Yang S, Hnilo JJ, Fiorino M, Potter GL (2002) NCEP-DOE AMIPII reanalysis (R-2). Bull Amer Meteor Soc 83:16311643. DOI: 10.1175/BAMS-83-11-1631

Karnauskas KB, Seager R, Giannini A, Busalacchi AJ (2013) A simple mechanism for the climatological midsummer drought along the Pacific coast of Central America. Atmósfera 26:261-281. DOI: 10.1016/S0187-6236(13)71075-0

Kousky VE (1988) Pentad outgoing longwave radiation climatology for the south american sector. Revista Brasileira de Meteorologia 3:217-231.

URL: http://www.rbmet.org.br/port/revista/ revista_artigo.php?id_artigo $=394$.

Liebmann B, Smith CA (1996) Description of a complete (interpolated) outgoing longwave radiation dataset. Bull Amer Meteor Soc 77:1275-1277. DOI: 10.1175/1520-0477-77.6.1274

Liebmann B, Camargo SJ, Seth A, Marengo JA, Carvhalo LMV, Allured D, Fu R, Vera CS (2007) Onset and end of the rainy season in South America in observations and the ECHAM 4.5 atmospheric general circulation model. J Clim 20:20372050. DOI: $10.1175 /$ JCLI4122.1

Magana V, Amador J, Medina S (1999) The midsummer drought over Mexico and Central America. J Clim 12:1577-1588. DOI: 10.1175/15200442(1999)012<1577:TMDOMA > 2.0.CO;2

Maldonado T, Rutgersson A, Alfaro E, Amador J, Claremar B (2006) Interannual variability of the midsummer drought in Central America and the connection with sea surface temperatures. Adv Geosci 42:35-50. DOI: 10.5194/adgeo-42-35-2016
Mapes BE, Buenning N, Kang I-S, Kiladis GN, Schultz DM, Weickmann KM (2004) Strides, steps and stumbles in the march of the seasons. (unpublished manuscript); URL: https://www. semanticscholar.org/paper/ Strides,-steps-and-stumbles-in-the-march-of -the-Mapes -Buenning/7696a2713a971d08f9abe4 180a868d8ed5ff3a9c. Accessed 22 December 2019

Marengo JA, Liebman B, Kousky VE, Filizola NP, Wainer IC (2001) Onset and end of the rainy season in the Brazilian Amazon basin. J Clim 14:833-852. DOI: 10.1175/15200442(2001)014<0833:OAEOTR $>2.0 . \mathrm{CO} ; 2$

Marteau R, Moron V, Philippon N (2009) Spatial coherence of monsoon onset over western and central Sahel (1950-2000). J Clim 22:1313-1324. DOI: $10.1175 / 2008$ JCLI2383.1

Martinez C, Goddard L, Kushnir Y, Ting M (2019) Seasonal climatology and dynamical mechanisms of rainfall in the Caribbean. Clim Dyn 53:825-846. DOI: $10.1007 / \mathrm{s} 00382-019-04616-4$

May DA, Parmeter MM, Olszewski DS, McKenzie BD (1998) Operational processing of satellite sea surface temperature retrievals at the Naval Oceanographic Office. Bull Am Meteorol Soc 79:397-407. DOI: 10.1175/15200477(1998)079<0397:OPOSSS > 2.0.CO;2

Mestas-Nuñez AM, Enfield DB, Zhang C (2007) Water vapor fluxes over the intra-Americas sea: seasonal and interannual variability and association with rainfall. J Clim 20:1910-1922. DOI: 10.1175/JCLI4096.1.

Michelangeli P-A, Vautard R, Legras B (1995) Weather regimes: Recurrence and quasi-stationarity. $\mathrm{J}$ Atmos Sci 52:1237-1256. DOI: 10.1175/15200469(1995)052<1237:WRRAQS>2.0.CO;2

Moron V, Gouirand I (2003) Seasonal modulation of the El Niño southern oscillation relationship with sea level pressure anomalies over the North Atlantic in October-March 1873-1996. Int J Climatol 23:143155. DOI: $10.1002 /$ joc. 868

Moron V, Gouirand I, Taylor M (2015) Weather types across the Caribbean basin and their relationship with rainfall and sea surface temperature. Clim Dyn 47:601-621. DOI: 10.1007/s00382-015-2858-9

Moron V, Frelat R, Jean-Jeune PK, Gaucherel C (2015) Interannual and intra-annual variability of rainfall in Haiti (1905-2005). Clim Dyn 45:915-932. DOI: $10.1007 / \mathrm{s} 00382-014-2326-\mathrm{y}$

Moron V, Robertson AW (2014) Interannual variability of Indian summer monsoon rainfall onset date at local scale. Int J Climatol 34:1050-1061. DOI: $10.1002 /$ joc. 3745 
Moron V, Robertson AW (2020) Tropical seasonal-tosubseasonal predictability types. npj Clim Atmos Sci, 3: 4. DOI: 10.1038/s41612-020-0107-3

Moron V, Robertson AW, Boer R (2009) Spatial coherence and seasonal predictability of monsoon onset over Indonesia. J Clim 22:840-850. DOI: 10.1175/2008JCLI2435.1

Moron V, Robertson AW, Qian J-H (2010) Local versus regional-scale characteristics of monsoon onset and post-onset rainfall over Indonesia. Clim Dyn 34:281299. DOI: $10.1007 / \mathrm{s} 00382-009-0547-2$

Muñoz E, Busalacchi AJ, Nigam S, Ruiz-Barradas A (2008), Winter and summer structure of the Caribbean low-level jet,. J Clim 21:1260-1276. DOI: 10.1175/2007JCLI1855.1

Peña M, Douglas MW (2002) Characteristics of wet and dry spells over the Pacific side of Central America during the rainy season. Mon Wea Rev 130:3054-3073. DOI: 10.1175/15200493(2002)130<3054:COWADS >2.0.CO;2

Poveda G, Mesa OJ (2000) On the existence of Lloró (the rainiest locality on Earth): Enhanced ocean-land-atmosphere interaction by low-level jet. Geophys Res Lett 27:1675-1678. DOI: $10.1029 / 1999$ GL006091

Pozo-Vázquez D, Esteben-Parra MJ, Rodrigo FS, Castro-Díez Y (2001) The association between ENSO and winter atmospheric circulation and temperature in the North Atlantic region. J Clim 14:3408-3420. DOI: 10.1175/15200442(2001)014<3408:TABEAW>2.0.CO;2

Reynolds RW, Rayner NA, Smith TM, Stokes TC, Wang W (2002) An improved in situ and satellite SST analysis for climate. J Clim 15:1609-1625. DOI: 10.1175/15200442(2002)015<1609:AIISAS > 2.0.CO;2

Sáenz F, Durán-Quesada AM (2015) A climatology of low level wind regimes over Central America using a weather type classification approach. Front Earth Sci 3, 15 pages. DOI: $10.3389 /$ feart.2015.00015

da Silva AE, de Carvalho LMV (2007) Large-scale index for South America monsoon (LISAM). Atmosph Sci Lett 8:51-57. DOI: 10.1002/asl.150

Small RJO, de Szoeke SP, Xie S-P (2007) The Central American midsummer drought: Regional aspects and large-scale forcing. J Clim 20:4853-4873. DOI: $10.1175 / J C L I 4261.1$

Spence JM, Taylor MA, Chen AA (2004) The effect of concurrent sea-surface temperature anomalies in the tropical Pacific and Atlantic on Caribbean rainfall. Int J Climatol 24:1531-1541. DOI: 10.1002/joc.1068 Stensrud DJ, Gall RL, Mullen SL, Howard KW (1995) Model climatology of the Mexican mon- soon. J Clim 8:1775-1794. DOI: 10.1175/15200442(1995)008<1775:MCOTMM > 2.0.CO;2

Straus DM, Molteni F (2004) Circulation regimes and SST forcing: Results from large GCM ensembles. J Clim 17:1641-1656. DOI: 10.1175/15200442(2004)017<1641:CRASFR > 2.0.CO;2

Tang BH, Neelin JD (2004) ENSO influence on Atlantic hurricanes via tropospheric warming. Geophys Res Lett 31:L24204. DOI: 10.1029/2004GL021072

Taylor MA, Enfield DB, Chen AA (2002) Influence of the tropical Atlantic versus the tropical Pacific on Caribbean rainfall. J Geophys Res Ocean 107:3127. DOI: 10.1029/2001JC001097

Taylor MA, Stephenson TS, Owino A, Chen AA, Campbell JD (2011) Tropical gradient influences on the Caribbean rainfall. J Geophys Res 116:D00Q08. DOI: 10.1029/2010JD015580

Vautard R, Mo KC, Ghil M (1990) Statistical significance test for transition matrices of atmospheric Markov chains. J Atmos Sci 47:1926-1931. DOI: 10.1175/15200469(1990)047<1926:SSTFTM>2.0.CO;2

Wang C (2007) Variability of the Caribbean low-level jet and its relation to climate. Clim Dyn 29:411-422. DOI: 10.1007/s00382-007-0243-z

Wang C, Lee S-K (2007) Atlantic warm pool, Caribbean low-level jet and their potential on Atlantic hurricanes. Geophys Res Lett 34:L02703. DOI: $10.1029 / 2006$ GL028579

Wang C, Lee S-K, Enfield DB (2007) Impact of the Atlantic warm pool on the summer climate of Western hemisphere. J. Clim 20:5021-5040. DOI: $10.1175 /$ JCLI4304.1

Xie S-P (1999) A dynamic ocean-atmosphere model of the tropical Atlantic decadal variability. J Clim 12:64-70. DOI: 10.1175/15200442(1999)012<0064:ADOAMO>2.0.CO;2

Xie S-P, Okumura Y, Miyama T, Timmermann T (2008) Influences of Atlantic climate change on the tropical Pacific via the Central American isthmus. J Clim 21:3914-3928. DOI: 10.1175/2008JCLI2231.1

Xie S-P, Philander SGH (1994) A coupled oceanatmosphere model of relevance to the ITCZ in the eastern Pacific. Tellus A46:340-350. DOI: $10.3402 /$ tellusa.v46i4.15484

Xie S-P, Xu H, Kessler WS, Nonaka M (2005) Air-sea interaction over the Eastern Pacific warm pool: Gap winds, thermocline dome and atmospheric convection. J Clim 18:5-20. DOI: 10.1175/JCLI-3249.1

Zhang C (1993) Large-scale variability of atmospheric deep convection in relation to sea surface temperature in the tropics. J Clim 6:1898-1913. DOI: 10.1175/1520-
54 
